\title{
COMMENTS
}

\section{KEEPING WOMEN OUT OF THE EXEGUTIVE SUITE: THE COURTS' FAILURE TO APPLY TITLE VII SGRUTINY TO UPPER-LEVEL JOBS}

\author{
TRACY ANBINDER BARON†
}

\section{INTRODUCTION}

Despite women's ${ }^{1}$ recent gains in fields that have been historically dominated by men, the upper reaches of most professions remain disproportionately male. ${ }^{2}$ Thus, although the percentage of female lawyers, professors, and middle managers has risen steadily, the percentage of female law partners, tenured professors, and senior executives is still much lower than many would expect. ${ }^{3}$ Some call this phenomenon the "glass ceiling." Others call it a

† B.A. 1986, Duke University; J.D. Candidate 1995, University of Pennsylvania. I would like to thank Professor Susan Sturm, who sponsored my independent study project, for her guidance and enthusiasm. Thanks are also due to Hilary Siegel, Scott Goldberg, and Dan Dex for their careful editing, and to my parents, Madeline and Stephen Anbinder, for their constant support of my academic pursuits. Finally, a special thank you goes to my husband Rob for tolerating my unconventional work hours and for believing in me every step of the way. This Comment is dedicated to him, with love.

Although my discussion will focus on women, most of the analysis is equally applicable to people of color. For women of color the analysis is even more applicable. A growing body of literature on "intersectionality" discusses the unique relationship between women of color and the law. See generally Paulette M. Caldwell, A Hair Piece: Perspectives on the Intersection of Race and Gender, 1991 DUkE L.J. 365 (discussing the legal acceptance of discrimination against African-American women in the context of employer prohibition of braided hair); Kimberle Crenshaw, Demarginalizing the Intersection of Race and Sex: A Black Feminist Critique of Antidiscrimination Doctrine, Feminist Theory, and Antiracist Politics, 1989 U. CHI. LEGAL F. 139 (noting the prevalence of viewing race and gender discrimination as mutually exclusive); Angela P. Harris, Race and Essentialism in Feminist Legal Theory, 42 STAN. L. REV. 581 (1990) (arguing that the current feminist theory, by trying to create a unified voice, has tended to exclude the voice of African-American women); Marlee Kline, Race, Racism, and Feminist Legal Theory, 12 HARV. WOMEN's L.J. 115 (1989) (attempting to reexamine white feminist theory from the perspective of women of color).

2 See infra notes 9-12 and accompanying text.

${ }^{3}$ See Deborah L. Rhode, Perspectives on Professional Women, 40 STAN. L. REv. 1163, 1178 (1988) (noting that women in law, academia, and management have not moved into "the positions of greatest power, prestige, and economic reward"). 
"plateau." But whatever its name, it is keeping productive members of the work force underemployed and unrewarded.

While there are many possible explanations for this persistent problem, the courts are at least partly responsible. As the courts assumed a more active role in scrutinizing employment decisions for lower-level jobs, those jobs became more accessible to women and minorities. ${ }^{4}$ Despite their professed concern for equal opportunities at the upper levels of employment, ${ }^{5}$ the courts do not scrutinize upper-level employment decisions as closely as lower-level employment decisions. When the position at stake is a prestigious whitecollar job, courts tend to defer to the employer, expressing fears of second-guessing the employer or infringing on the employer's professional judgment. ${ }^{6}$

The courts' deference in this area is not wholly unjustified. Employment decisions for upper-level jobs are virtually always based on subjective judgments of candidates' talents and abilities. ${ }^{7}$ These types of decisions can be more difficult to review than typical lowerlevel employment decisions, which can usually be based on objective factors such as words typed per minute or widgets assembled per hour. This difficulty inherent in reviewing upper-level employment decisions, however, does not justify abdication of the duty to uphold Title VII's proscription against employment discrimination. ${ }^{8}$ Nor should a concern for taking too much discretion out of employers' hands keep the courts from acting. Rather, the courts should develop an analytical system that can identify and address the individual and institutional biases that affect employers' decisions.

4 See Elizabeth Bartholet, Application of Title VII to Jobs in High Places, 95 HARV. L. REv. 947, 948 \& n.1 (1982) (noting that lower-level jobs have become more available to African-Americans and members of other groups that have been traditionally discriminated against).

${ }^{5}$ See Ezold v. Wolf, Block, Schorr \& Solis-Cohen, 983 F.2d 509, 527 (3d Cir. 1992) (noting that upper-level subjective decisions are not "insulated from judicial review"), cert. denied, 114 S. Ct. 88 (1993); Bennun v. Rutgers State Univ., 941 F.2d 154, 174 (3d Cir. 1991) (" $[\mathrm{N}]$ o special deference is to be paid to the tenure and promotion decisions of universities when they are scrutinized under Title VII . . . ."), cert. denied, 112 S. Ct. 956 (1992).

${ }^{6}$ See Rhode, supra note 3, at 1193-94 (discussing courts' deference to employer judgment); see also Bartholet, supra note 4, at 967-78 (citing and discussing cases which show courts' reluctance to scrutinize upper-level employment decisions).

${ }^{7}$ See infra notes 73-74 and accompanying text.

${ }^{8}$ Title VII of the Civil Rights Act of 1964 made it unlawful for an employer to discriminate "because of" race, color, religion, sex, or national origin. Pub. L. No. 88-352, $\$ \$ 701-18,78$ Stat. 241, 253-66 (1964) (codified as amended at 42 U.S.C. $\$ \S 2000$ e to $2000 \mathrm{e}-17$ (1988 \& Supp. V 1993)). 
A legal framework that recognizes and condemns such biases would create incentives for employers to restructure their decision-making in ways that would minimize the impact of those biases, while still preserving a great degree of employer discretion over upperechelon employment decisions.

This Comment examines the courts' failure to address upperlevel employment discrimination effectively and proposes a solution that would allow them to do so. Part I describes the sociological and psychological factors that create subtle barriers to women's advancement in the upper levels of most professions. Part II explains how the courts' refusal to scrutinize the intricacies of upper-level employment decisions has made it nearly impossible for upper-level plaintiffs to prevail on Title VII claims. Part III proposes a Title VII analysis that would permit courts to scrutinize upper-level employment decisions without unnecessarily limiting employer discretion. By closely analyzing the elements of subjective decision-making systems, the courts can better distinguish between those employers who have reduced the influence of gender bias in their employment decisions and those employers who have not. In this way, courts can apply Title VII scrutiny to upper-level employment decisions without forcing employers to abandon valid subjective criteria.

\section{Why the Glass Ceiling Persists}

Although the statistics describing women's presence in upperlevel jobs $^{9}$ vary from source to source, the persistence of a sizable disparity between the presence of men and women in such jobs is unmistakable. From a recent review of the corporate headquarters of ninety-four Fortune 1000 companies, the U.S. Department of Labor estimated that although women represented $37.2 \%$ of all employees, they represented only $16.9 \%$ of those at all levels of

${ }^{9}$ Many positions do not lend themselves to easy categorization as either upperlevel or lower-level jobs. There is, however, an unmistakable yet unspoken difference in the way courts approach employment discrimination claims depending on the socioeconomic status of the job at stake. One important distinguishing factor is the level of discretionary decision-making that a position involves. Alternatively, the dichotomy adopted by Professor Elizabeth Bartholet, who first documented this difference in legal treatment, is still relevant. Under Bartholet's framework, bluecollar jobs, including supervisory and highly skilled craft jobs, as well as white-collar jobs with limited status and power are treated as lower-level jobs. Middle- and uppermanagement jobs, professional positions, and other jobs requiring advanced degrees are considered upper-level jobs. See Bartholet, supra note 4, at 948 n.2. 
management and $6.6 \%$ of executive-level managers. ${ }^{10}$ A 1990 survey by the UCLA Anderson Graduate School of Management and the executive search firm Korn/Ferry International found similar statistics, concluding that minorities and women hold less than five percent of the top executive positions in the one thousand largest U.S. corporations, a figure only slightly higher than it was in 1979, when they held fewer than three percent of such positions. ${ }^{11}$ In 1991 the Feminist Majority Foundation predicted that it would take 475 years for women to reach equality with men in executive positions if the present rate of progress were to continue. ${ }^{12}$

Part of this disparity may be due to real or imagined differences between the way women and men pursue their careers. This view attributes the lower achievement levels of professional women to the fact that women, more often than men, interrupt their careers to raise children and prefer to sacrifice work in order to spend more time with their families. ${ }^{13}$ Thus, women may consciously or unconsciously choose jobs that are less demanding on their time, and therefore less powerful and less financially rewarding. Others explain the disparity as a mere temporary phenomenon resulting from the lag time needed for recent women entrants into the job market to work their way up to the most prestigious positions. ${ }^{14}$

These arguments, however, only partially explain the persistent gap between men and women in upper-level jobs. Observers ranging from feminist scholars to the Bush Administration Labor Department agree that women's underrepresentation in the elite ranks of their professions is not solely due to their preferences and work habits. The U.S. Department of Labor's recent report on the glass ceiling phenomenon concluded that "the progress of minori-

${ }^{10}$ See U.S. DeP'T OF LABOR, A REPORT ON THE Glass CEILING INITIATIVE 6 (1991). The statistics were equally disturbing for racial and ethnic minorities. While racial and ethnic minorities represented $15.5 \%$ of all employees, they represented only $6.0 \%$ of those at all levels of management and only $2.6 \%$ of executive level managers. See $i d$.

"See id.

12 See ANN M. MORRISON ET AL., BREAKING the Glass CeIling 7 (updated ed. 1992) (citing THE FEMINIST MAJORITY FOUNDATION, EMPOWERING WOMEN IN BUSINESS 2 (1991)).

${ }^{13}$ See Rhode, supra note 3, at 1181; Jaclyn Fierman, Why Women Still Don't Hit the Top, FORTUNE, July 30, 1990, at 40,54 (noting that "virtually every woman interviewed for [the] article acknowledged the heavy-and sometimes painful-demands of juggling family or personal life and the fast track").

${ }^{14} \mathrm{See}$, e.g., Fierman, supra note 13 , at 42 (noting that "the average CEO is in his mid-50s and most business schools began admitting women in significant numbers only in the early 1970s, which puts them around fortysomething today"). 
ties and women in corporate America is affected by more than qualifications and career choices." ${ }^{15}$ The report noted that "[w]hile some assert that minorities and women have neither been in the workforce long enough, nor have the needed credentials, the vast majority of available research information points to artificial barriers as a significant cause for why minorities and women have not advanced further in corporate America." 16 An increasing body of evidence suggests that men and women approach their careers more similarly than most people assume. ${ }^{17}$ Deborah Rhode, Professor of Law and Director of Stanford University's Institute for Research on Women and Gender, argues that the barriers to women's professional advancement cannot be explained as mere "cultural lag or employee choice," but rather result from a combination of intentional discrimination and "more subtle forms of socialization patterns and institutional structures that the law has politely overlooked. ${ }^{18}$

\section{A. Social and Psychological Factors That Affect Women in Upper-Level Jobs}

In order to fully comprehend why the law's efforts to eliminate gender discrimination have been only partially successful, one must understand the social and psychological factors that cause discrimination in upper-level jobs. As the following discussion demonstrates, discrimination that affects upper-level women is often unintentional and unconscious. Because discrimination in the executive suite differs from discrimination on the factory floor, it is not surprising that legal doctrines designed with lower-level jobs in mind do not adequately address upper-level discrimination.

\section{Unconscious Tendency to Promote Socially Similar People}

One disadvantage that women face at the upper levels of most professions is that many people prefer colleagues who are similar to themselves. As long as men make up the overwhelming majority of high-level professionals, they will probably continue to promote other men more often than they promote women unless they are

${ }^{15}$ U.S. DEP'T OF LABOR, supra note 10 , at 4.

${ }^{16} \mathrm{Id}$. at 18.

${ }^{17}$ See MORRISON ET AL., supra note 12, at 69 (noting that "women are remarkably similar to men in their characteristics, abilities, and motives").

${ }^{18}$ Rhode, supra note 3 , at 1180 . 
held accountable by being forced to justify their employment decisions. This preference to work with similar people may simply be the result of men feeling most comfortable when they are around other men. Research has shown that "top executives tend to promote people into leadership positions who are as much like them as possible" because they are "simply more comfortable with and seem to gravitate toward people like themselves." 19

Organizational studies have shown that leaders are "likely to show preference for socially similar subordinates and help them get ahead. ${ }^{20}$ Thus, in a bureaucratic corporation, managers tend to "rely on outward manifestations to determine who is the 'right sort of person."'21 Rosabeth Moss Kanter, a professor of business administration at Harvard Business School and a noted expert on organizational behavior, explains this phenomenon:

Because of the situation in which managers function, because of the position of managers in the corporate structure, social similarity tends to become extremely important to them. The structure sets in motion forces leading to the replication of managers as the same kind of social individuals. And the men who manage reproduce themselves in kind. ${ }^{22}$

This tendency to promote people who are similar may be even more pronounced as one climbs the professional ladder. The desire to work with those who are similar results from an attempt to reduce the amount of uncertainty in the workplace. ${ }^{23}$ The more discretion a job entails, the more the person performing that job must be trusted, and decision-makers feel most comfortable trusting people similar to themselves. In high-level jobs, where uncertainty abounds, it becomes crucial that "decision-makers [be able] to work together closely in at least the harmony of shared understanding and a degree of mutual trust." ${ }^{24}$ Thus, "[w]e expect a direct

${ }^{19}$ MORRISON ET AL., supra note 12, at 125 (quoting Basia Hellwig, The Breakthrough Generation: 73 Women Ready to Run Corporate America, WORKING WOMAN, Apr. 1985, at 148,148 ).

${ }^{20}$ ROSABETH M. KANTER, MEN AND WOMEN OF THE CoRporation $47-48$ (1977); see also Fierman, supra note 13, at 42 ("It may seem surprising in an era sometimes labeled postfeminist, but working closely with the opposite sex continues to make many male executives uncomfortable.").

${ }^{21}$ KANTER, supra note 20 , at 48 . One commentator described this tendency for men to reproduce themselves in their own image as "homosexual reproduction." Id. (citing WILBERT MOORE, THE CONDUCT OF THE CORPORATION 109 (1962)).

${ }^{22} I d$.

${ }^{23}$ See id. at 53.

${ }^{24} I d$. 
correlation ... between the degree of uncertainty in a position-the extent to which organizations must rely on personal discretion-and a reliance on 'trust' through 'homosocial reproduction'-selection of incumbents on the basis of social similarity. ${ }^{n 25}$

\section{Inferior Work Assignments}

Another commonly cited impediment to women's success is the inferior work assignments they often receive. The low expectations for achievement that upper-level men often have for women may partially explain this phenomenon. ${ }^{26}$ Whatever the cause, less demanding assignments can negatively affect women's performance. The district court judge in Ezold v. Wolf, Block, Schorr E Solis-Cohen noted this phenomenon. ${ }^{27}$ As one of the firm's partners admitted, Nancy Ezold, whom the firm denied partnership, was penalized because she had been given inferior assignments:

[T] he perception that she is not able to grasp complex issues or handle complex cases ... appears to be a product of how Sy Kurland viewed Nancy's role when she was initially hired. For the first few years Sy would only assign Nancy to non-complex matters, yet, at evaluation time, Sy, and some other partners would qualify their evaluations by saying that Nancy does not work on complex matters. Nancy was literally trapped in a Gatch 22. The Chairman of the Litigation Department would not assign her to complex cases, yet she received negative evaluations for not working on complex cases. ${ }^{28}$

The American Bar Association has noted this phenomenon as well. A recent report by its Commission on Women in the Profession states that "women are receiving different types of case assignments from those given to men, and are sometimes steered away from major litigation [and] commercial matters. ${ }^{29}$ It is not surprising

${ }^{25}$ Id. at 54; see also Fierman, supra note 13, at 42 (quoting a partner at a headhunting firm who notes that corporate males are "not really sure the women will come through for them. They just don't trust them as much as the guys with whom they talk football.").

${ }^{26}$ See infra notes $44-48$ and accompanying text.

27751 F. Supp. 1175,1178 (E.D. Pa. 1990), rev'd, 983 F.2d 509 (3d Cir. 1992), cert. denied, 114 S. Ct. 88 (1993).

${ }^{28}$ Id. at 1179 (quoting a letter from a partner concerned about Ezold's situation to the firm's Executive Committee); see also U.S. DEP'T OF LABOR, supra note 10, at 5 ("[C]areer enhancing assignments . . . were often not as available to minorities and women.").

${ }^{29}$ COMM. ON WOMEN IN THE PROFESSION, AM. BAR ASS'N, REPORT TO THE HOUSE OF DELEGATES 11 (1988). 
that women succeed less frequently than men at the upper levels of employment when the evidence indicates that they are not given the same chances as men to prove themselves.

\section{Gender Stereotypes}

Stereotypes about women's abilities and aspirations also influence their ability to obtain upper-level jobs. ${ }^{30}$ A stereotype can be defined as a judgment or assessment of an individual based on generalizations about a group to which that individual belongs. ${ }^{31}$ Women professionals face stereotypical views of women as well as stereotypical images of the traits necessary to succeed in certain professions. For instance, if litigators are stereotyped as being aggressive males, a woman who is not perceived as aggressive will not be expected to succeed. This may be true even if in reality successful litigators are not necessarily aggressive or male. ${ }^{32}$

Since jobs become associated with certain groups of people through past experience, jobs that have historically been performed by men tend to be considered "men's work." Studies show that the current proportions of men and women in different occupations significantly influence societal beliefs about who should pursue those occupations. ${ }^{33}$ In one study, ninety-five bank supervisors were asked to make promotion decisions from hypothetical personnel files in which the qualifications were equal but the gender was varied. The supervisors decided to promote the men far more often than the women. ${ }^{34}$

${ }^{30}$ See Fierman, supra note 13, at 42 (citing a recent survey of Fortune 1000 CEOs in which $80 \%$ of the respondents said that there were barriers keeping women from reaching the top and $81 \%$ of the CEOs who acknowledged the barriers named "stereotyping" and "preconceptions" as the most important problems). See generally Nadine Taub, Keeping Women in Their Place: Stereotyping Per Se as a Form of Employment Discrimination, 21 B.C. L. REV. 345 (1980) (discussing stereotyping in the workplace in the context of employment discrimination law).

${ }^{31}$ The generalization may be true as to the group, although not necessarily true for the individual. It also may be "only partially or not at all true." Mary F. Radford, Sex Stereotyping and the Promotion of Women to Positions of Power, 41 HASTINGs L.J. 471, 487 (1990). In Price Waterhouse v. Hopkins, 490 U.S. 228 (1989), the American Psychological Association filed an amicus curiae brief outlining the consistent research on sex stereotyping, noting that over 300 articles had appeared on the subject between 1974 and 1987. See Radford, supra, at $486 \mathrm{nn} .58-59$.

32 This type of bias is known as a "prototype" because it results from the "images associated with members of a particular occupation." Rhode, supra note 3 , at 1188 .

s3 See, e.g., Radford, supra note 31, at 491 .

s4 See id. at 492 (citing Benson Rosen \& Thomas H. Jerdee, Influence of Sex Stereotypes on Personnel Decisions, 59 J. APPLIEd PSYGHOL. 9, 11 (1974)). 
The characteristics assumed to be necessary in certain types of workers often conflict with the characteristics assumed to be present in certain types of people. Thus, the stereotype that litigators must be aggressive would not negatively affect employers' judgments of women without the additional stereotype that women are not aggressive. Although few would argue that there are no differences between the sexes, ${ }^{35}$ it is becoming increasingly apparent that judging people by their gender is often both inaccurate and destructive. Adjectives typically used to describe men include aggressive, independent, unemotional, competitive, analytical, assertive, and self-reliant. Adjectives typically used to describe women include gentle, quiet, yielding, loyal, shy, cheerful, neat, and understanding. ${ }^{36}$ Thus, studies reveal that the stereotypical characterizations of males typically match the commonly held perceptions of "good managers," whereas the stereotypical characterizations of females do not. ${ }^{37}$

It is not surprising that women have difficulty succeeding in upper-level jobs given the two sets of contradictory stereotypes with which women must contend. If a woman wants to be a successful litigator, should she be aggressive, to fit the stereotype of a litigator, or demure, to fit the stereotype of a woman? To advance in their careers, women must simultaneously conform to certain masculine traits and certain feminine traits. If a woman displays too much masculinity she will be called overbearing and demanding; if she displays too much femininity she will be called weak and unassertive. ${ }^{38}$ A recent work on the glass ceiling noted what was required of the women executives who had succeeded:

It was essential that they contradict the stereotypes that their male

${ }^{35}$ See Joan C. Williams, Deconstructing Gender, 87 MiCH. L. REV. 797, 800 (1989) ("Gender differences do exist: that is, men as a group differ from women as a group not only on the basis of biological 'sex' differences, but on the basis of social 'gender' differences."). See generally CAROL GILLIGAN, IN A DIFFERENT VOICE (1982) (discussing differences between female and male modes of thinking regarding relationships, identity, and morality); Robin West, Jurisprudence and Gender, 55 U. CHI. L. REv. 1 (1988) (arguing that women, by virtue of the possibility of pregnancy, are connected to human life in ways that men are not).

${ }^{36}$ See Radford, supra note 31, at 494.

${ }^{37}$ Id. at 487; see also Rhode, supra note 3, at 1182 (discussing the disparity between the perceptions of ideal women and of successful professionals).

${ }^{38}$ Arlene Johnson, who directs work force studies at the Conference Board, a business research organization in New York, notes the difficulty this phenomenon creates for women: "'It's as if we're being asked to play a Beethoven sonata in two octaves." Fierman, supra note 13 , at $46-47$. 
executives and coworkers had about women-they had to be seen as different, "better than women" as a group. But they couldn't go too far, to forfeit all traces of femininity, because that would make them too alien to their superiors and colleagues. In essence, their mission was to do what wasn't expected of them, while doing enough of what was expected of them as women to gain acceptance. The capacity to combine the two consistently, to stay within a narrow band of acceptable behavior, is the real key to success. ${ }^{39}$

Because women are forced to fit their behavior into a narrow range of acceptability, whereas men are not, women are being held to standards that differ substantively from those to which their male colleagues are held. This gender-specific standard is no less destructive simply because many of those who enforce it do so unconsciously.

\section{Unequal Performance Standards}

Evidence suggests that just as stereotypes cause employers to scrutinize women's personality traits differently than men's, genderbased preconceptions lead employers to scrutinize women's professional performance more harshly than men's. Many observers report that women are required to perform better than men to achieve the same level of success. For example, the U.S. Department of Labor reports that women professionals felt "they were not held to the same performance measures as men and believed that they had to work twice as hard. ${ }^{.40}$ Corporate insiders admit that "[w]omen are ... expected to be extremely competent, often even more competent than men in a number of respects ${ }^{\text {nII }}$ and that the "women who are successful in their company had been screened very, very thoroughly . . . more thoroughly, in fact, than the men as a whole." ${ }^{42}$ Kanter reports that professional women-even those who did not consider themselves victims of discriminationrecognized this phenomenon when they admitted "that they felt they had to 'work twice as hard' and expend more energy than the average man to succeed. ${ }^{\text {"43 }}$

${ }^{39}$ MORRISON ET AL., supra note 12, at 54-55.

${ }^{40}$ U.S. DEP'T OF Labor, PIPElines of Progress: AN Update on the Glass CEILING INITIATIVE 35 (1992).

${ }^{41}$ MORRISON ET AL., supra note 12 , at 58.

${ }^{42} \mathrm{Id}$. at 59 .

${ }^{43}$ KANTER, supra note 20, at 238-39. 
Expectations of failure may also affect women's promotability and performance. The American Bar Association's Commission on Women in the Profession recently noted a difference in the presumed capabilities of men and women when it reported that "women must prove their competence, while men must prove their incompetence." ${ }^{n 4}$ Indeed, "[w]omen report[ed] that they are often treated with a presumption of incompetence, to be overcome only by flawless performance, whereas they see men attorneys treated with a presumption of competence overcome only after numerous significant mistakes." ${ }^{\text {45 }}$ This expectation that women will fail not only requires women to perform better in order to be recognized, but may very well influence them to perform worse, because low expectations of success often become self-fulfilling prophecies. ${ }^{46}$

Even when women perform as well as men, studies suggest that their achievements often are not credited in the same way as men's. For example, men's success is more likely to be explained by ability and their failure by bad luck. Women's success, on the other hand, is likely to be explained by good luck while their failure is likely to be explained by lack of ability. ${ }^{47}$ Because evaluations of ability are extremely important for hiring and promotion decisions, this difference can be devastating to women's careers. ${ }^{48}$

\section{Personal Connections}

Evidence suggests that the comparatively low availability of sponsors or mentors for women may be another factor that negatively affects their career prospects at the upper levels. Although finding a sponsor is important for managers of both genders, ${ }^{49}$ it may be even more crucial for women. ${ }^{50}$ These mentors, whether acting formally or informally, help women to appear more influential and powerful, provide behavioral advice, and even help win promotions. ${ }^{51}$ Unfortunately, finding a sponsor may be more difficult for women than for men. As one candid corporate insider pointed out, the problem is identification: "Boy wonders rise under

4 COMM. ON WOMEN IN THE PROFESSION, supra note 29, at 4.

15 Id. at 12.

${ }^{16}$ See Rhode, supra note 3, at 1189 (arguing that low expectations, as reflected by lower salaries and less demanding assignments, result in poor job performance).

${ }^{17}$ See id. at $1188-89$.

${ }^{18}$ See id. at 1189.

${ }^{19}$ See KANTER, supra note 20, at 181.

${ }^{50}$ See id. at 183 .

${ }^{51}$ See id. 
certain power structures. They're recognized by a powerful person because they are very much like him. He sees himself, a younger version, in that person.... Who can look at a woman and see themselves?"52

Women's careers may also suffer because women tend to have fewer opportunities to form informal social networks with their colleagues. In a 1987 survey, executive women cited "old boy networks" as a common form of subtle discrimination..$^{53}$ These "networks" may take the form of female law associates not being included in the poker games with male partners or female sales representatives not being invited to the golf game with the male regional vice president. ${ }^{54}$ Such social exclusion can occur even in the office. As one female vice president noted, "It's tough. The ways I am excluded are very subtle . . . before meetings or during the break, I am often left by myself while the men chat with each other." 55 Although such oversights may seem inconsequential at first, they can often be critical when accumulated over the course of an entire career. These unofficial gatherings frequently represent the chance for deals to be struck or professional connections to be cultivated.

Attorney Elizabeth Hishon's suit against the prominent Atlanta law firm of King and Spalding ${ }^{56}$ exemplifies this subtle barrier for women. ${ }^{57}$ One of the ways King and Spalding attempted to justify denying her partnership was by pointing out that she did not socialize enough, was too quiet and reserved, and “'just didn't fit in.' ${ }^{\text {58 }}$ The partners with these complaints, however, did not consider the possibility that the firm's atmosphere may have contributed to Hishon's failure to participate enthusiastically in the firm's formal and informal social gatherings. Before Hishon's arrival, the firm had employed only one female attorney in its

52 Id. at 184.

5s Gregory B. Northcraft \& Barbara A. Gutek, Point-Counterpoint: Discrimination Against Women in Management-Going, Going, Gone or Going but Never Gone?, in WOMEN IN MANAGEMENT 219, 224 (Ellen A. Fagenson ed., 1993).

${ }^{54}$ See Fierman, supra note 13, at 54 (describing a female executive who attended an executive outing, only to find that the luncheon grill was located in an extension of the men's locker room).

${ }^{55}$ Northcraft \& Gutek, supra note 53, at 224.

${ }^{56}$ See Hishon v. King \& Spalding, 467 U.S. 69 (1984).

${ }^{57}$ See Rhode, supra note 3 , at 1190.

${ }^{58}$ James Stewart, Are Women Lawyers Discriminated Against at Large Law Firms?, WALL ST. J., Dec. 20, 1983, at 1, 17 (quoting a member of the firm's hiring committee). 
ninety-nine-year history, ${ }^{59}$ and the partners had arranged a swimsuit competition for its summer associates while Hishon's lawsuit was pending, awarding a prize to the female "body we'd like to see more of. ${ }^{n 60}$

\section{Life as a Token}

As already discussed, it may be more difficult for women to succeed in traditionally male professions because the actual distribution of the sexes in a job affects perceptions of who should be performing that job. ${ }^{61}$ Being part of a small minority at work can have other detrimental effects on women's careers as well. ${ }^{62}$ Whether men outnumber women or Whites outnumber Blacks, the problem of tokenism remains the same. It is the condition of being the few among the many; it is the "rarity and scarcity" that has an effect. $^{63}$

Kanter has identified several difficulties associated with being a token in the workplace that are particularly problematic for upperlevel women. First, they are seen simultaneously as representative of their category (especially when they fail) and as unusual exceptions (especially when they succeed). Second, while they are constantly made aware of the differences between themselves and the majority, they also must pretend that those differences do not exist. Third, they are made to feel visible and "on stage," but are kept away from the backstage "where the dramas are cast." Fourth, during times such as social events when the majority are the most relaxed, tokens may experience the highest degree of stress. Finally, despite the fact that many suffer from a sense of isolation, they may feel pressure to dissociate from others who are like them. ${ }^{64}$

What is most worrisome about tokenism is that it seems to be

${ }^{59}$ King and Spalding's first female attorney, Antha Mulkey, started at the firm as a secretary to partner Hughes Spalding and retired in 1977 without ever being considered for partnership. Hishon, who was hired in 1977, was the first woman to be hired as a regular associate. See id.

${ }^{60} I d$. at 1 (quoting one of the firm's partners).

${ }^{61}$ See supra notes 33-37 and accompanying text.

62 See KANTER, supra note 20, at 206-42 (discussing the particular problems confronting tokens); Rhode, supra note 3, at 1191 (discussing gender biases faced by token women).

${ }^{63}$ KANTER, supra note 20, at 207.

${ }^{6}$ See id. at 239; see also Rhode, supra note 3, at 1191 (discussing the problems facing professional token women). 
self-perpetuating. ${ }^{65}$ Women tokens feel pressure not to associate with other women, leading them to fail to help other women or even to try actively to keep out new women. Meanwhile, unsuccessful women tokens give the organization an excuse not to hire new women, unless those new women are so unusually talented that they are clearly different from most other women. Because the men in power may prefer working with other men, ${ }^{66}$ they are unlikely to go to great lengths to hire more women absent strong pressure to do so. Because tokenism is self-perpetuating, "outside intervention is required to break the cycles created by the social composition of groups."67

\section{The Power of Unconscious Bias}

Most of the discriminatory barriers facing women in upper-level employment are erected unintentionally and unconsciously. ${ }^{68}$ The tendency for managers to reproduce themselves is probably not pursued consciously. ${ }^{69}$ Most people whose judgments are skewed by stereotypical ideas of the way women and men should behave are unaware that they are not being completely impartial. ${ }^{70}$ Few decision-makers consciously expect women to perform better or work harder than men in order to achieve the same degree of success. ${ }^{71}$ Unfortunately, unconscious biases can impede women's careers as effectively as consciously erected barriers. In fact, since antidiscrimination law addresses conscious biases more effectively than unconscious biases, ${ }^{72}$ unconscious biases may be even more harmful to women.

${ }^{65}$ See KANTER, supra note 20, at 241.

${ }^{66}$ See id. at 241-42; see also supra part I.A.1.

${ }^{67}$ KANTER, supra note 20 , at 242.

${ }^{68}$ See Rhode, supra note 3, at 1188 ("Although . . . doubts [about the competence of women] are no longer generally aired in polite company, they still emerge in studies of unconscious bias."). Rhode explains that unconscious gender bias manifests itself in three ways: (1) prototypes, the images we associate with people who perform certain jobs; (2) schema, the "personal characteristics and situational factors" that we use to understand people's behavior; and (3) scripts, the way we define appropriate conduct in a certain situation. Id.; see also Charles R. Lawrence III, The Id, the Ego, and Equal Protection: Reckoning with Unconscious Racism, 39 STAN. L. REV. 317 (1987) (discussing the prevalence of unconscious bias in the race discrimination context and examining its implications for antidiscrimination law that focuses on discriminatory intent).

${ }^{69}$ See supra part I.A.1.

${ }^{70}$ See supra part I.A.3.

${ }^{71}$ See supra part I.A.4.

${ }^{72}$ See infra notes $108-11$ and accompanying text. 


\section{B. Institutional Factors}

Whereas the factors described above demonstrate the ways in which individual decision-makers can affect women's success, institutional practices can, to a great extent, control the impact that these individual biases will have on high-level employment decisions. The systems and policies that shape the workplace as an institution can go far to mitigate or compound the destructive effects of these individual biases.

Is the environment at work conducive to frank discussions about biases and stereotypes? Does management make it clear that efforts to reduce bias will be rewarded? Are decision-makers required to articulate specific reasons for their decisions and judge candidates based on clearly defined criteria? Are they encouraged to think about whether their decision might have been inadvertently influenced by improper considerations? The answers to these questions have a crucial impact on the extent to which women can thrive in the upper levels of a particular workplace.

The pervasiveness of subjective employment criteria is one institutional factor that significantly affects women's experiences in the upper strata of the professional world. Powerful and prestigious jobs typically require complex skills that can only be measured subjectively. ${ }^{73}$ Thus, whereas decisions about lower-level jobs frequently are based on objective criteria such as words typed per minute, decisions about upper-level positions often depend on subjective assessments of the candidate's previous performance and future potential. ${ }^{74}$

Because subjective decision-making gives the decision-maker considerably more personal discretion, the process becomes more susceptible to the expression of the unconscious biases outlined above. ${ }^{75}$ Industrial psychologists, aware of this tendency, warn personnel directors to pay careful attention to the dangers of subjective rating systems. ${ }^{76}$ Their concern arises from the potential for these amorphous criteria to be distorted by the evaluator's personal biases as well as by problems such as spotty observation by the evaluator and unequal chances for the employee to demonstrate

73 See Bartholet, supra note 4, at 955.

74 See id.; Radford, supra note 31, at 483-84.

75 See supra part I.A.

${ }^{76}$ See Donald L. Garuth et al., Staffing the Contemporary ORganization 229 (1988); WAYNe F. CAScio, APPLIEd PSyChology IN PERSONNEL MANAGEMENT 66 (3d ed. 1987). 
proficiency. ${ }^{77}$ Both of these factors were apparently at work when Nancy Ezold's inferior work assignments denied her adequate exposure to partners, which in turn affected her evaluations. ${ }^{78}$

Legal scholars have also warned that subjective decisions are susceptible to the influence of stereotypes and biases. Elizabeth Bartholet commented that "[s]ubjective systems ... allow for the expression both of conscious bias and of the unconscious bias that is likely to result in the exclusion of persons who are visibly different from those doing the selecting." ${ }^{79}$ Mary Radford also noted this phenomenon: "When looking for leaders in law firms, accounting firms, or newsrooms, decision-makers search for more than just physical ability or technical competence. Personal attributes take on prime importance. Stereotypical notions of how persons of each gender should or will act (or look or dress) then become determinative. ${ }^{n 0}$ Because upper-level jobs are more likely to be filled on the basis of subjective judgments, women vying for upper-level jobs are more likely to suffer the effects of unconscious biases than women competing for lower-level jobs.

Thus, the social and psychological factors that affect women's actual and perceived performance can have varying degrees of impact on ultimate employment decisions, depending on whether the institution takes steps to control the influence of biases in its decision-making processes. While an employer may not be able to control the personal biases influencing an individual decisionmaker, the employer can and should adjust the institutional framework in order to minimize the impact of those biases. Although no employer could ever completely eliminate the subjectivity involved in upper-level employment decisions-nor should an employer want to-employers can eliminate excess amounts of personal discretion. In this way, the institutional framework can encourage the individual actors to make more reasoned, fair, and unbiased decisions.

77 See CASCIO, supra note 76, at 66.

${ }^{78}$ See Ezold v. Wolf, Block, Schorr \& Solis-Cohen, 751 F. Supp. 1175, 1178-79

(E.D. Pa. 1990), rev'd, 983 F.2d 509 (3d Cir. 1992), cert. denied, 114 S. Ct. 88 (1993).

${ }^{79}$ Bartholet, supra note 4 , at 955.

${ }^{80}$ Radford, supra note 31 , at 484 . 


\section{THE COURTS' RESPONSE}

\section{A. The Current State of Employment Discrimination Law}

\section{Title VII}

The courts' attempts to eliminate the disadvantages facing women in upper-level employment have not been completely successful. ${ }^{81}$ This effort began with Title VII of the Civil Rights Act of $1964,{ }^{82}$ which made it unlawful for an employer to discriminate "because of" race, color, religion, sex, or national origin. ${ }^{83}$ Title VII was the first significant national effort to eliminate employment discrimination. ${ }^{84}$ For the first time the federal courts

${ }^{81}$ See generally Bartholet, supra note 4 (arguing that courts have applied a different standard when evaluating discrimination in upper-level and lower-level jobs); Radford, supra note 31 (analyzing cases in which professional women were denied promotions because they were perceived as lacking the personal qualifications required for upperlevel jobs).

8242 U.S.C. $\$ \S 2000$ e to $2000 \mathrm{e}-17$.

83 The statute states that:

It shall be an unlawful employment practice for an employer-

(1) to fail or refuse to hire or to discharge any individual, or otherwise to discriminate against any individual with respect to his compensation, terms, conditions, or privileges of employment, because of such individual's race, color, religion, sex, or national origin; or

(2) to limit, segregate, or classify his employees or applicants for employment in any way which would deprive or tend to deprive any individual of employment opportunities or otherwise adversely affect his status as an employee, because of such individual's race, color, religion, sex, or national origin.

$\S 2000 \mathrm{e}-2(\mathrm{a})$. It is interesting to note that "sex" did not appear in the original draft of the bill and seems to have been included almost by accident. See Tracy L. Bach, Note, Gender Stereotyping in Employment Discrimination: Finding a Balance of Evidence and Causation Under Title VII, 77 MINN. L. REv. 1251, 1256 n.23 (1993). House Report 7152, later called the Civil Rights Act of 1964, was introduced by Representative Emanuel Celler on June 20, 1963, without the word "sex." The amendment that added the word "sex" was introduced by Representative Howard Smith, an opponent of the bill, while the bill was before the House Judiciary Committee, in an apparent effort to defeat the entire bill. No organization petitioned Congress to add the word "sex," nor was there any testimony on the amendment before the Judiciary Committee. See id.

${ }^{84}$ Previous federal laws had been unsuccessful at solving the problem. The Equal Pay Act of 1963, Pub. L. No. 88-38, 77 Stat. 56, (codified at 29 U.S.C. $\$ 206$ (d) (1988)), was too narrow, addressing only wage discrimination where the two sexes performed "equal work." The National Labor Relations Act, Pub. L. No. 74-198, 49 Stat. 449 (1935) (codified as amended at 29 U.S.C. \$§ 151-169 (1988)), addressed discrimination only indirectly, as part of the union's duty of fair representation. Executive Orders, such as the effort to eliminate discrimination by government contractors, only applied to a small number of employers. See, e.g., Exec. Order No. 
had the responsibility of reviewing the employment practices of most of the nation's employers. ${ }^{85}$

\section{Individual Disparate Treatment}

The courts have developed three distinct theories of liability in their application of Title VII: individual disparate treatment, systemic disparate treatment, and disparate impact. ${ }^{86}$ In an individual disparate treatment case, the issue is whether the employer treated the individual plaintiff less favorably because of her race, color, religion, sex, or national origin. ${ }^{87}$ The Supreme Court set out a three-step model for proving individual disparate treatment in McDonnell Douglas Corp. v. Green ${ }^{88}$ and then refined that model in Texas Department of Community Affairs v. Burdine. ${ }^{\mathbf{9 9}}$ First, the plaintiff must establish a prima facie case of discrimination by eliminating the most common reasons for a job applicant to be rejected-namely, that she did not apply, she was not qualified, or the position was not open. ${ }^{90}$ Once this is established, the inference is that, unless the employer can come forward with another plausible reason, discrimination must have been the cause of the decision. ${ }^{91}$ Second, the burden of production shifts to the employer to articulate a legitimate, nondiscriminatory reason for the decision. ${ }^{92}$ And third, if the employer carries this burden, the plaintiff must show that the employer's stated reason for its decision was a

10,925, 26 Fed. Reg. 1977 (1961) (focusing on curtailing discrimination among government contractors). State laws proscribing discrimination often were either nonexistent, especially in those states where discrimination was most severe, or poorly enforced. See MiChaEl J. ZimMER eT Al., CASES AND MATERIALS ON EMPLOYMENT DISCRIMINATION 23-24 (2d ed. 1988).

${ }^{85}$ See ZIMMER ET AL., supra note 84, at 23-24. Title VII applies to all private employers with 15 or more employees. See 42 U.S.C. $\$ 2000 \mathrm{e}(\mathrm{b})$.

${ }^{86}$ See McDonnell Douglas Corp. v. Green, 411 U.S. 792 (1973) (individual disparate treatment); International Bhd. of Teamsters v. United States, 431 U.S. 324, 335-36 n.15 (1977) (systemic disparate treatment); Griggs v. Duke Power Co., 401 U.S. 424 (1971) (disparate impact); see also Zimmer et al., supra note 84, at 40.

${ }^{87}$ See Teamsters, 431 U.S. at 336 n.15.

${ }^{88} 411$ U.S. 792 (1973).

${ }^{89} 450$ U.S. 248 (1981).

${ }^{90}$ See McDonnell Douglas, 411 U.S. at 802 (holding that plaintiff establishes a prima facie case by showing that she belonged to a protected class, that she applied for and was qualified for a job for which the employer was seeking applicants, that she was rejected despite her qualifications, and that the position remained open and the employer continued to seek applicants with the plaintiff's qualifications after she was rejected).

${ }^{91}$ See id.

${ }^{92}$ See id. 
"pretext" for discrimination. ${ }^{93}$ Because it will generally be easy for the plaintiff to establish a prima facie case, ${ }^{94}$ and because the employer will usually be able to articulate some legitimate reason for its decision, most individual disparate treatment cases will depend on the plaintiff's ability to prove that the employer's reason was a pretext. ${ }^{95}$ Because the plaintiff carries the burden of persuasion at all times, ${ }^{96}$ the plaintiff has the ultimate burden of proving that the employer's proffered reason for rejecting her was not the "real" reason. ${ }^{97}$

${ }^{93}$ Id. at 804. But see St. Mary's Honor Ctr. v. Hicks, 113 S. Ct. 2742, 2756 (1993) (holding that rejection of employer's proffered reason will not necessarily lead to judgment for the plaintiff).

${ }^{34}$ See Ezold v. Wolf, Block, Schorr \& Solis-Cohen, 983 F.2d 509, 523 (3d Cir. 1992) ("Because the prima facie case is easily made out, it is rarely the focus of the ultimate disagreement."), cert. denied, 114 S. Ct. 88 (1993).

${ }_{95}^{95}$ See Miles v. M.N.C. Corp., 750 F.2d 867, 870 (11th Cir. 1985) ("Because of the employee's easy burden of establishing a prima facie case and the employer's normal ability to articulate some legitimate nondiscriminatory reasons for its actions, most disparate treatment cases turn on the plaintiff's ability to demonstrate that the nondiscriminatory reason offered by the employer was a pretext for discrimination.").

${ }_{96}^{96}$ See Texas Dep't of Community Affairs v. Burdine, 450 U.S. 248, 253 (1981) ("The ultimate burden of persuading the trier of fact that the defendant intentionally discriminated against the plaintiff remains at all times with the plaintiff.").

${ }^{97}$ Since human decisions are rarely the result of only one motive, what happens when it appears that discrimination was one of many reasons for the employer's decision? The Supreme Court first addressed these "mixed motives" cases in Price Waterhouse v. Hopkins, 490 U.S. 228 (1989). A sharply divided Court held that a plaintiff successfully carries her burden if she shows that a prohibited factor, such as gender, "was $a$ factor in the employment decision at the moment it was made." Id. at 241 (first emphasis added). The employer could avoid liability, however, by showing that the same decision would have been made even if it had not considered the prohibited factor. See id. at 242.

Price Waterhouse also represented the first in-depth discussion by the Supreme Court of the legal relevance of sex stereotyping. The Court clearly stated that an employer's differential treatment of men and women based on sex stereotypes constitutes sex discrimination:

As for the legal relevance of sex stereotyping, we are beyond the day when an employer could evaluate employees by assuming or insisting that they matched the stereotype associated with their group, for "[i]n forbidding employers to discriminate against individuals because of their sex, Congress intended to strike at the entire spectrum of disparate treatment of men and women resulting from sex stereotypes." An employer who objects to aggressiveness in women but whose positions require this trait places women in an intolerable and impermissible catch 22: out of a job if they behave aggressively and out of a job if they do not. Title VII lifts women out of this bind.

Id. at 251 (citation omitted) (quoting Los Angeles Dep't of Water \& Power v. Manhart, 435 U.S. 702, 707 n.13 (1978)).

The Civil Rights Act of 1991, Pub. L. No. 102-166, 105 Stat. 1071 (codified in 


\section{Systemic Disparate Treatment}

In a systemic disparate treatment case, the ultimate issue is still whether the employer intentionally discriminated, but the plaintiff is a group instead of an individual. Usually brought as a class action or by the Equal Employment Opportunity Commission (EEOC) on behalf of a group of employees, a systemic disparate treatment case attempts to demonstrate either an explicit policy of treating members of one group differently or a "pattern or practice" of doing so. ${ }^{98}$ Plaintiffs establish a prima facie case by using statistical evidence to show a disparity between the percentage of class members in the pool of qualified applicants and the percentage of class members in the workforce. ${ }^{99}$ Once the plaintiffs have established the prima facie case, the defendant has the burden of production to articulate a different explanation for the statistical disparity. ${ }^{100}$ Thus, the empirical assumption underlying systemic disparate treatment is that without another explanation, the percentage of class members in the workforce would be equal to the percentage of class members in the applicant pool. A statistical imbalance is not in itself a violation, but constitutes evidence that can aid in proving that the employer is discriminating. ${ }^{101}$

scattered sections of 42 U.S.C.), altered the disparate treatment theory of employment discrimination law somewhat. It codified Price Waterhouse's notion of mixed motives, providing that it is unlawful for one of the prohibited factors to be "a motivating factor for any employment practice, even though other factors also motivated the practice." 42 U.S.C. \$ 2000e-2(m) (Supp. V 1993). It also modified Price Waterhouse, in that proof of an illegitimate motivating factor actually establishes a violation instead of merely shifting the burden of proof to the defendant. See id. If the defendant demonstrates that the same decision would have been made even without the unlawful motivating factor, however, the remedy available to the plaintiff will be limited so that she cannot receive a monetary award or reinstatement. See $\$ 2000$ e5(g)(2)(B)(ii). Presumably attorney's fees would still be available. See $\$ 2000 \mathrm{e}-5(\mathrm{k})$.

${ }_{98}^{8}$ See, e.g., International Bhd. of Teamsters v. United States, 431 U.S. 324, 334 (1977) (examining whether petitioner company engaged in a "pattern or practice" of employment discrimination).

${ }_{99}$ See, e.g., Bazemore v. Friday, 478 U.S. 385, 398 (1986); Hazelwood Sch. Dist. v. United States, 433 U.S. 299, $307-08$ (1977); Teamsters, 431 U.S. at 339.

${ }^{100}$ See Teamsters, 431 U.S. at 329.

${ }^{101}$ As the Teamsters Court noted:

Statistics showing racial or ethnic imbalance are probative in a case such as this one only because such imbalance is often a telltale sign of purposeful discrimination; absent explanation, it is ordinarily to be expected that nondiscriminatory hiring practices will in time result in a work force more or less representative of the racial and ethnic composition of the population in the community from which employees are hired.

Id. at 340 n. 20 . 


\section{Disparate Impact}

The issue in a disparate impact case is whether an employment practice that is neutral on its face impacts one group more negatively than another. Two Supreme Court cases, Griggs v. Duke Power Co. ${ }^{102}$ and Albemarle Paper Co. v. Moody, ${ }^{103}$ established a three-step process for determining liability. First, the plaintiff must establish a prima facie case of disparate impact by showing that the challenged practice, although facially neutral, affects one group more harshly than another. ${ }^{104}$ This is usually accomplished by using statistics to show that the seemingly neutral practice, when applied over time to large numbers of people, affects a protected class more harshly than an unprotected class. ${ }^{105}$ Second, once the plaintiff establishes a prima facie case, the employer has the burden of proving that, despite its negative impact on a protected class, the practice in question was justified by business necessity. ${ }^{106}$ Third, even if the employer shows business necessity, the plaintiff can show that the employer is using the practice as a pretext for discrimination by pointing to another practice that would serve the same purpose without a discriminatory impact. ${ }^{107}$

102401 U.S. 424 (1971).

${ }^{103} 422$ U.S. 405 (1975).

${ }^{104}$ See id. at 425 .

${ }^{105}$ See Connecticut v. Teal, 457 U.S. 440, 446 (1982) (noting that "to establish a prima facie case of discrimination, a plaintiff must show that the facially neutral employment practice had a significantly discriminatory impact"); Dothard v. Rawlinson, 433 U.S. 321, 329 (1977) (holding that a prima facie case was established when plaintiffs proved that minimum height and weight requirements disproportionately affected women applying for positions as correctional officers).

${ }^{106}$ See Griggs, 401 U.S. at 432 ("Congress has placed on the employer the burden of showing that any given requirement must have a manifest relationship to the employment in question.").

${ }_{107}$ See Albemarle, 422 U.S. at 425. Two Supreme Court decisions in the late 1980s made substantial changes to disparate impact analysis: Watson v. Fort Worth Bank \& Trust, 487 U.S. 977 (1988), and Wards Cove Packing Co. v. Atonio, 490 U.S. 642 (1989). Watson was the first case in which the Court specifically held that disparate impact analysis may be applied to subjective employment practices. See 487 U.S. at 991. In Wards Cove, on the other hand, the Court significantly weakened disparate impact liability. In dictum, the Wards Cove Court eased the employer's burden by redefining business necessity to require only a reasonable justification instead of strict necessity: "The touchstone of this inquiry is a reasoned review of the employer's justification for his use of the challenged practice. . . . [T]here is no requirement that the challenged practice be 'essential' or 'indispensable' to the employer's business for it to pass muster ...." 490 U.S. at 659. Wards Cove also changed the prior assumption that business necessity was an affirmative defense for the employer by placing the burden of persuasion in showing a lack of business necessity on the plaintiff. Thus, "the employer carries the burden of producing evidence of a business 


\section{The Shortcomings of the Three Theories of Employment \\ Discrimination Liability in the Context of Upper-Level Cases}

The three traditional theories of employment discrimination liability, as they are frequently applied, do not adequately address most cases involving upper-level jobs. In systemic disparate treatment cases, courts often refuse to infer discrimination solely from a pattern of exclusion demonstrated by statistics, and instead insist on anecdotal evidence of discriminatory motive. ${ }^{108}$ This evidence is frequently either unavailable or available only indirectly through expert witness testimony. Furthermore, these same courts often discount the value of expert testimony in establishing patterns of bias within the workplace. ${ }^{109}$ In addition, despite the Supreme Court's pronouncements that unintentional behavior such as stereotyping is legally relevant, ${ }^{110}$ the plaintiff in an individual disparate treatment case still must persuade the court that "the employer actually relied on her gender in making its decision. ${ }^{n 111}$

Another difficulty that upper-level plaintiffs face in attempting to bring individual disparate treatment cases stems from the Supreme Court's recent decision in St. Mary's Honor Center v. Hicks. ${ }^{112}$ In that case, the Court held that the plaintiff will not necessarily prevail even if she proves that the employer's articulated

justification for his employment practice. The burden of persuasion, however, remains with the disparate-impact plaintiff." Id.

The Civil Rights Act of 1991 modified disparate impact theory by overruling much of Wards Cove. For the first time, Congress explicitly codified the concept of disparate impact. See 42 U.S.C. \$ $2000 \mathrm{e}-2(\mathrm{k})(1)$. The Act rejected the Wards Cove dictum that gave the plaintiff the burden of showing a lack of business necessity. Now, the employer has the burden of persuading the court that the challenged practice was job related and consistent with business necessity. See $\$ 2000 \mathrm{e}-2(\mathrm{k})(1)(\mathrm{A})(\mathrm{i})$. The Act did not, however, clarify the definition of business necessity.

${ }^{108}$ See EEOC v. Sears, Roebuck \& Co., 839 F.2d 302, 311 (7th Cir. 1988) (noting plaintiff's failure to come forward with anecdotal evidence of discriminatory employment practices); Vicki Schultz, Telling Stories About Women and Work: Judicial Interpretations of Sex Segregation in the Workplace in Title VII Cases Raising the Lack of Interest Argument, 103 HARV. L. REV. 1749, 1793 (1990) (noting judges' insistence that plaintiffs present anecdotal evidence of discrimination to refute the lack of interest argument). But see Stender v. Lucky Stores, 803 F. Supp. 259, 319 (N.D. Cal. 1992) (noting that discriminatory intent may be inferred from statistical evidence).

${ }^{109}$ See, e.g., Sears, 839 F.2d at 321 (stating reasons for finding plaintiff's expert witness testimony unpersuasive).

${ }^{110}$ See Price Waterhouse v. Hopkins, 490 U.S. 228, 251 (1989).

${ }^{111} I d$.

112113 S. Ct. 2742 (1993). 
reason was not the real reason for the decision. Once the employer articulates an explanation for its decision, the Court reasoned, it has met its burden of production, and the McDonnell Douglas framework of presumptions drops out. ${ }^{113}$ The Court can then require more direct evidence that the real reason for the employer's decision was discrimination. ${ }^{114}$ This kind of direct evidence will be especially difficult for upper-level plaintiffs to produce, given the subtle factors at work in many high-level employment decisions.

Furthermore, the individual disparate treatment model's focus on the individual plaintiff often obscures the important group dynamics of the workplace, and thus fails to detect the forms of sex discrimination most pervasive in high-level jobs. The district court in Ezold compensated for this shortcoming of the individual disparate treatment approach by trying to place the facts of Ezold's individual case in the broader context of the entire work environment. It did not treat the partnership decision in a vacuum, but rather took into account Ezold's admonishment for being too involved in "women's issues," the criticism she received for displaying stereotypically male personality traits, and the firm's weak policy on sexual harassment. ${ }^{115}$ The court of appeals, however, rejected the district court's analysis, and was unpersuaded that these broader workplace dynamics might indicate that the firm's proffered explanations could be a pretext for discrimination. ${ }^{116}$

Systemic disparate treatment also poses formidable challenges for upper-level plaintiffs. Institutions have a limited number of upper-level jobs, and few candidates will have the qualifications to contend for them. The small number of both opportunities and applicants thus makes accurate statistical analysis virtually impossible. Courts, recognizing this fundamental principle of statistics, have frequently warned plaintiffs that statistical evidence will not carry much weight if the sample size is too small. ${ }^{117}$

113 See id. at 2747 (noting that under McDonnell Douglas Corp. v. Green, 411 U.S. 792 (1973), the presumption in favor of the plaintiff's discrimination claim only shifts the burden of production to the employer, while the burden of persuasion remains with the plaintiff).

${ }^{114}$ See id. at 2749 (holding that plaintiff bears the burden of persuasion to prove that discrimination was the real reason for employer's decision).

${ }^{115}$ Ezold v. Wolf, Block, Schorr \& Solis-Cohen, 751 F. Supp. 1175, 1192 (E.D. Pa. 1990), rev'd, 983 F.2d 509 (3d Cir. 1992), cert. denied, 114 S. Ct. 88 (1993).

${ }^{116}$ See Ezold v. Wolf, Block, Schorr \& Solis-Cohen, 983 F.2d 509, 543-45 (3d Cir. 1992), cert. denied, 114 S. Ct. 88 (1993).

${ }^{11}$ See, e.g., International Bhd. of Teamsters v. United States, 431 U.S. 324, 340 n.20 (1977) (noting that small sample size may detract from trustworthiness of statisti- 
Unfortunately, the disparate impact theory of liability may not be an option either. First, like systemic disparate treatment, disparate impact theory's dependence on statistical evidence will be problematic for upper-level plaintiffs because of the small numbers of people involved in upper-level jobs. Second, disparate impact theory is intended to be applied to facially neutral practices that affect one group more harshly than another. ${ }^{118}$ With upper-level discrimination cases, however, the claim is that the practices are not truly facially neutral. Although the criteria according to which upper-level applicants are judged may appear neutral to those who apply them, the test used for women differs from the test used for their male colleagues. When this test consists of an unstructured set of highly subjective judgments, however, it is difficult to prove that the test applied to one group was different than the test applied to another. Third, because courts assume that subjective decisionmaking is appropriate for upper-level jobs, they tend to accept vague subjective systems without question. ${ }^{119}$ They frequently fail to recognize that legitimate subjective systems can be distinguished from arbitrary subjective systems. Finally, courts that interpret the Civil Rights Act of 1991 to allow the lenient standard of business necessity articulated by the Supreme Court in Wards Cove ${ }^{120}$ will be more likely to permit employers to continue using discriminatory

cal evidence); Mayor of Phila. v. Educational Equality League, 415 U.S. 605, 621 (1974) (validating the district court's concern for the small size of the statistical sample); Haskell v. Kaman Corp., 743 F.2d 113, 119 (2d Cir. 1984) (citing Teamsters and Educational Equality League); Parker v. Federal Nat'l Mortgage Ass'n, 741 F.2d 975, 980-81 (7th Cir. 1984) (holding that small sample size prevented statistics "from giving rise to a reasonable inference of discriminatory motive").

${ }^{118}$ See supra note 104 and accompanying text.

${ }^{119}$ See, e.g., Tuft v. McDonnell Douglas Corp., 581 F.2d 1304, 1306 (8th Cir. 1978) (examining a layoff system which included consideration of an employee's "attitude, experience, educational level and position"); Frausto v. Legal Aid Soc'y, 563 F.2d 1324, 1329 (9th Cir. 1977) (holding that "a poor interview, an unstable employment history, a poor reputation in the legal community, and the inability to get along with people" were valid and nondiscriminatory reasons for not hiring appellant); EEOC v. E.I. duPont de Nemours \& Co., 445 F. Supp. 223, 254-55 (D. Del. 1978) (holding, inter alia, that subjective evaluations reported by mainly white supervisory staff, which affected promotions of employees, were insufficient evidence of discrimination); see also Bartholet, supra note 4, at 976-77 (describing the more lenient standard applied to upper-level jobs).

${ }^{120}$ See, e.g., Faulkner v. Super Valu Stores, 3 F.3d 1419, 1429 (10th Cir. 1993) (using the Wards Cove standard of business necessity and stating that "[ $t$ ]he law on this matter is clearly established"). For a discussion of the apparent weakening of the business necessity standard in Wards Cove and the failure of the Civil Rights Act of 1991 to clarify the issue, see supra note 107. 
subjective employment criteria for upper-level jobs.

\section{B. The Courts Apply a Lower Level of Scrutiny to Upper-Level Employment Decisions}

\section{The Courts' Response to Subjective Decision-Making Systems}

When lower-level jobs are at stake, most circuit courts do not hesitate to point out that subjective employment criteria are susceptible to abuse because of the large amount of discretion they confer on the decision-maker. In fact, no matter what kind of job is at stake, the courts of appeals for nine federal circuits have specifically called for a more exacting level of judicial scrutiny when an employer has utilized subjective criteria in its hiring and promotion decisions. ${ }^{121}$

${ }^{121}$ See, e.g., Jauregui v. City of Glendale, 852 F.2d 1128, 1136 (9th Cir. 1988) ( $[\mathrm{T}]$ his circuit has cautioned 'that subjective practices are particularly susceptible to discriminatory abuse and should be closely scrutinized." (quoting Atonio v. Wards Cove Packing Co., 810 F.2d 1477, 1481 (9th Cir. 1987) (en banc), cert. denied, 485 U.S. 989 (1988))); Miles v. M.N.C. Corp., 750 F.2d 867, 871 (11th Cir. 1985) ("[S]ubjective evaluations ... provide a ready mechanism for ... discrimination."); Grano v. Department of Dev., 699 F.2d 836, 837 (6th Cir. 1983) (per curiam) ("[S]ubjective evaluation processes intended to recognize merit provide ready mechanisms for discrimination. . . . [T] The legitimacy of the articulated reason for the employment decision is subject to particularly close scrutiny where the evaluation is subjective and the evaluators themselves are not members of the protected minority."); Royal v. Missouri Highway \& Transp. Comm'n, 655 F.2d 159, 164 (8th Cir. 1981) ("[S]ubjective promotion procedures are to be closely scrutinized because of their susceptibility to discriminatory abuse. ... When the evaluation is in any degree subjective and when the evaluators . . . are not members of the protected minority, the legitimacy . . . of the articulated reason for the decision should be subject to particularly close scrutiny .... "); Davis v. Califano, 613 F.2d 957, 965 (D.C. Cir. 1979) ("“[C]ourts [must] be sensitive to possible bias in the hiring and promotion process arising from ... subjective definition[s] of employment criteria.' Appellee's promotion procedures . . . must be closely scrutinized because of their capacity for masking unlawful bias." (quoting Rogers v. International Paper Co., 510 F.2d 1340, 1345 (8th Cir.), vacated, 423 U.S. 809 (1975))); Stewart v. General Motors Corp., 542 F.2d 445, 450 (7th Cir. 1976) ("While some subjectivity is inevitable in filling jobs of an executive character, the total lack of objective standards . . . could only reinforce the prejudices, unconscious or not, which Congress in Title VII sought to eradicate as a basis for employment."), cert. denied, 433 U.S. 919 (1977); Barnett v. W.T. Grant Co., 518 F.2d 543, 550 (4th Cir. 1975) ("Nonobjective hiring standards are always suspect because of their capacity for masking racial basis [sic]. "); Muller v. United States Steel Corp., 509 F.2d 923, 928 (10th $\mathrm{Cir}$ ) (" $[\mathrm{P}]$ ersonal and subjective criteria encourage and foster discrimination."), cert. denied, 423 U.S. 825 (1975); Rowe v. General Motors Corp., 457 F.2d 348, 359 (5th Cir. 1972) (" $[\mathrm{P}]$ romotion/transfer procedures which depend almost entirely upon . . . subjective evaluation and favorable recommendation . . . are a ready mechanism for discrimination ... much of which can be covertly concealed . ..."). 
This concern about subjective employment decisions, however, seems to have a consistent impact only in cases in which lower-level jobs are at stake. In such cases, when there is evidence that the employment decision was based on highly subjective judgments, there seems to be a presumption that the subjective decision-making process was used to mask unlawful discrimination or was not jobrelated. ${ }^{122}$ With upper-level jobs, the courts seem to presume that the decision was not discriminatory, despite their professed concern for subjective evaluations. In these cases the courts still insist that the plaintiff prove that the subjective criteria were used by the defendant to disguise unlawful discrimination. ${ }^{123}$ In some circuits the courts ignore the dangers of subjective evaluations altogether. Instead of a higher-than-usual level of scrutiny, these courts apply a lower-than-usual level of scrutiny when confronted with subjective decisions about upper-level jobs. ${ }^{124}$

Why do courts react so differently to subjective decision-making systems used to fill lower-level jobs than they do to subjective decision-making systems used at higher levels? ${ }^{125}$ One explanation may be the presumption that subjective decision-making systems are necessary for high-level jobs but not for low-level jobs, for which the availability of quantitative, objective alternatives makes the use of subjective systems seem suspicious. The availability of an objective system also makes the court's decision to strike down the subjective system more palatable.

With upper-level jobs, on the other hand, some courts assume that completely subjective decision-making systems are the only

122 See, e.g., Jauregui, 852 F.2d at 1135-36; Miles, 750 F.2d at 871; Royal, 655 F.2d at 164; Stewart, 542 F.2d at 450-51; Bamett, 518 F.2d at 549-50; Muller, 509 F.2d at 928; Rowe, 457 F.2d at 359; see also Bartholet, supra note 4, at 975.

${ }^{123}$ See, e.g., Grano, 699 F.2d at 837 ("The ultimate issue . . . is whether the subjective criteria were used to disguise discriminatory action.").

${ }_{124}$ See, e.g., Ezold v. Wolf, Block, Schorr \& Solis-Cohen, 983 F.2d 509, 527 (3d Cir. 1992) ("We have cautioned courts on several occasions to avoid unnecessary intrusion into subjective promotion decisions . . . "), cert. denied, 114 S. Ct. 28 (1993); Kunda v. Muhlenberg College, 621 F.2d 532, 548 (3d Cir. 1980) ("Determinations about such matters as teaching ability, research scholarship, and professional stature are subjective, and unless they can be shown to have been used as the mechanism to obscure discrimination, they must be left for evaluation by the professionals . . ..").

125 The differences in the ways courts treat upper-level and lower-level discrimination cases are not limited to the way they react to evidence of overly subjective decision-making processes. There seems to be a general reluctance by the courts to scrutinize upper-level employment decisions. See Bartholet, supra note 4, at 979-80 (describing judges' tendency to identify with upper-level employers); Rhode, supra note 3, at 1194 (noting judges' sympathy for employers). 
feasible option. ${ }^{126}$ They do not explore the possibility that subjectivity is a matter of degree. They fear that holding in favor of the plaintiff would either force them to take the subjective decision out of the employer's hands and give it to the court, or disallow the employer from using any subjectivity at all. These courts act as if the absence of an objective decision-making option for upper-level jobs requires them to accept whatever subjective system the employer has chosen. Thus, the Ezold court noted "our society's commitment to free decision-making by the private sector in economic affairs" in order to justify "the difficult task a plaintiff faces in proving discrimination in the application of subjective factors." ${ }^{27}$ Rather than recognizing ways in which Wolf, Block could make its evaluation system more structured and less susceptible to bias, the court simply noted the dilemma that subjective systems represent for plaintiffs and preserved the employer's discretion.

At first glance it would seem that some of the recent developments in employment discrimination law could effectively address many of the perceived deficiencies in the law's treatment of upperlevel cases. Bartholet's main concern was that the Griggs type of disparate impact liability, ${ }^{128}$ which requires the employer to demonstrate the business necessity of a system that impacts more harshly on class members than non-class members, was not being applied to upper-level jobs, which typically entail subjective judgments on the part of the employer. ${ }^{129}$ In 1988, the Supreme Court seemed to respond by holding in Watson $v$. Fort Worth Bank $\mathcal{E}$ Trust that disparate impact analysis can be applied to subjective employment criteria. ${ }^{130}$ Pamela Perry objected to the Court's apparent abandonment of the business necessity standard in Wards Cove. ${ }^{131}$ Yet the Civil Rights Act of 1991 seemed to address that

${ }^{126}$ For example, the court of appeals in Ezold noted that the firm's decisionmaking system was subjective in order to justify its deferential approach. See $983 \mathrm{~F} .2 \mathrm{~d}$ at 527. The court did not attempt to determine whether the firm's system was more subjective than necessary, which would increase the likelihood that unconscious biases played a role. Instead, the Ezold court determined that all subjective promotion decisions should receive minimal judicial scrutiny. See id.

${ }^{127} I d$.

${ }^{128}$ See Griggs v. Duke Power Co., 401 U.S. 424 (1971); see also supra part II.A.4 (discussing the disparate impact theory of liability).

${ }^{129}$ See Bartholet, supra note 4 , at $955-59$.

130487 U.S. 977, 991 (1988).

131 Wards Cove Packing Co. v. Atonio, 490 U.S. 642, 659 (1989); Pamela L. Perry, Balancing Equal Employment Opportunities with Employers' Legitimate Discretion: The 
problem at least partially by placing the burden of persuasion back on the employer to show that the challenged practice is both job related and a business necessity. ${ }^{132}$ Mary Radford suggested that, in a mixed motives case, ${ }^{133}$ proof of an employer's use of an illegitimate motivating factor in an employment decision should itself establish a Title VII violation, instead of merely shifting the burden of proving causation to the defendant, ${ }^{134}$ an approach that the Supreme Court adopted in Price Waterhouse v. Hopkins. ${ }^{135}$ Again, however, the Civil Rights Act of 1991 adopted Radford's suggestion by declaring that in mixed motives cases, a plaintiff can establish unlawful discrimination by demonstrating that a prohibited criterion was a motivating factor for the employer. ${ }^{136}$

\section{Challenges Faced by Upper-Level Plaintiffs}

With these recent developments in employment discrimination law that seem to help upper-level plaintiffs, why does Title VII continue to fall short of providing an adequate remedy for discrimination against women in high-level jobs? One answer may be that disparate impact analysis, which would seem to provide the appropriate analysis for unconsciously discriminatory employment practices, ${ }^{137}$ is not really available. Disparate impact theory focuses on whether a facially neutral policy impacts female employees more adversely than male employees. The plaintiff must use statistics to show that there is a nontrivial disparity in the way the challenged policy affects women compared to men. ${ }^{138}$ In upper-

Business Necessity Response to Disparate Impact Discrimination Under Title VII, 12 INDUS. REL. L.J. 1, 2-7 (1990).

132 See 42 U.S.C. $\$ 2000 \mathrm{e}-2(\mathrm{k})(1)(\mathrm{A})(\mathrm{i})$. Note that the Civil Rights Act of 1991 did not clarify the definition of "business necessity." Thus, the weakened definition suggested by Wards Cove dicta may still be of some relevance. See 490 U.S. at 659; see also supra note 107.

133 For a brief discussion of mixed motives cases, see supra note 97.

134 See Radford, supra note 31, at 529.

135490 U.S. 228, $252-53$ (1989).

${ }^{136}$ See 42 U.S.C. $\$ 2000 \mathrm{e}-2(\mathrm{~m})$.

${ }^{137}$ As Bartholet points out, in a disparate treatment case, the employer need only articulate a rational explanation for its employment decision. Then the plaintiff assumes the burden of proving that the explanation was a pretext. In a disparate impact case, on the other hand, the employer must show that business necessity demands that the current system be maintained. "Rational explanations abound for why blacks are assigned to less desirable jobs or receive lower salaries. Proof that business necessity demands that they be treated this way is a different matter." Bartholet, supra note 4 , at 1004.

${ }^{138}$ The EEOC uses the "four-fifths rule." The Uniform Guidelines on Employee 
level employment, however, decisions are typically made on an individualized basis, ${ }^{139}$ making it difficult for the plaintiff to have a large enough sample size to make an adequate statistical showing. ${ }^{140}$ There is also a widespread perception that subjective criteria, which play a significant role in upper-level hiring decisions, cannot be validated. ${ }^{141}$ Thus, the court will not expect the employer to show business necessity by validating its subjective system. ${ }^{142}$ Furthermore, plaintiffs may feel obligated to rely on disparate treatment theory rather than disparate impact theory because they do not have enough information. Plaintiffs will not feel comfortable claiming that a particular practice used by the employer has a disparate impact when often they do not know at the outset precisely what practices the employer uses. ${ }^{143}$ This is

Selection state that "[a] selection rate for any race, sex, or ethnic group which is less than four-fifths (4/5) (or eighty percent) of the rate for the group with the highest rate will generally be regarded by the Federal enforcement agencies as evidence of adverse impact." 29 C.F.R. § 1607.4(D) (1993).

${ }^{199}$ See Rhode, supra note 3, at 1193 n.162 (noting that "decisionmaking is individualized" in upper-level employment).

${ }^{140}$ See supra note 117 and accompanying text.

${ }^{141}$ See Watson v. Fort Worth Bank \& Trust, 487 U.S. 977, 980 (1988) (noting that validation techniques endorsed by the EEOC often cannot be used with subjective selection systems); Frazier v. Consolidated Rail Corp., 851 F.2d 1447, 1455 (D.C. Cir. 1988) ("some components of a selection device may be so subjective that ... validation will be impossible"); Davis v. City of Dallas, 777 F.2d 205, 217 (5th Cir. 1985) (noting that subjective criteria are virtually impossible to validate formally), cert. denied, 476 U.S. 1116 (1986); United States v. City of Montgomery, Ala., 775 F. Supp. 1450,1459 (M.D. Ala. 1991) (stating that subjective promotion guidelines are "difficult, if not impossible to validate").

Validation is a technique for correlating successful performance on the employer's selection criteria with successful performance on the job at issue. The EEOC guidelines provide a detailed explanation of accepted validation techniques that employers may use to justify their application of selection criteria that have an adverse impact on a protected class. See 29 C.F.R. $§ 1607$ (1993).

${ }^{142}$ See Bartholet, supra note 4, at 987 . Bartholet notes that

courts in upper level cases often seem to assume that subjective systems are inherently incapable of being validated. This assumption is implicit in many of the cases upholding such systems on the ground that some kind of subjective system clearly seems appropriate, without further inquiry into whether the system at issue is valid.

Id.

143 Bartholet notes:

This initial plaintiff strategy may be sensible when the employment scheme at issue is obscure and all that is clear is that it results in differential treatment-as is often the case in upper level employment. Plaintiffs cannot always know, when they first file suit, how defendants will eventually describe their employment policies; it is not possible for plaintiffs to show that unknown policies have a disparate impact. 
more likely to be a problem for upper-level jobs with subjective, undefined evaluation criteria.

Because of these difficulties with the current structure of disparate impact liability, most upper-level employment discrimination plaintiffs will use the disparate treatment theory of liability. In addition, because most upper-level cases will not involve large enough numbers for an adequate statistical showing, ${ }^{144}$ most upperlevel plaintiffs will rely on individual, as opposed to systemic, disparate treatment theory. Unfortunately, individual disparate treatment will also be problematic for upper-level plaintiffs because of its emphasis on intent. ${ }^{145}$ In individual disparate treatment cases, the ultimate issue will usually be whether the employer's stated reason for not hiring or promoting the plaintiff is a pretext for a discriminatory reason (pretext cases) or whether a discriminatory factor was part of the reason for the employer's decision (mixed motives cases). Ostensibly, the plaintiff will not need direct evidence that discriminatory intent was involved. As Justice Powell explained in Texas Department of Community Affairs $v$. Burdine, ${ }^{146}$ the plaintiff has the "ultimate burden of persuading the court that she has been the victim of intentional discrimination. She may succeed in this either directly by persuading the court that a discriminatory reason more likely motivated the employer or indirectly by showing that the employer's proffered explanation is unworthy of credence. ${ }^{n 147}$

In practice, however, upper-level plaintiffs often will need to have direct evidence of the employer's discriminatory motives. When faced with the prospect of second-guessing another professional's subjective opinion of the skills and abilities of the plaintiff, some judges feel uncomfortable. They may presume that the expert's opinion was correct and not influenced by illegitimate factors. Without strong, almost "smoking gun" evidence, many courts simply defer to the employer's judgment. For example, as Chief Judge Dolores Sloviter recently stated in a case involving academic tenure, "I do not believe that it is proper or desirable for the courts of this circuit to become involved in substantive tenure and promotion decisions in the academic setting unless the evidence of

Id. at 1006.

${ }^{144}$ See supra note 117 and accompanying text.

145 See supra note 111 and accompanying text.

146450 U.S. 248 (1981).

${ }^{147} \mathrm{Id}$. at 256. 
discriminatory action is unmistakable. ${ }^{n 148}$ The court of appeals in Ezold took a similar posture. While noting early in the opinion that the plaintiff was required to prove that the employer's proffered justification was a pretext for discrimination "by a preponderance of the evidence, ${ }^{149}$ the court later noted that the pretext must be "obvious or manifest" when subjective factors are involved. ${ }^{150}$

Unfortunately, "unmistakable" evidence of discrimination will be nearly impossible to obtain. As discussed above, many of the factors that make a woman's experiences in the office different from a man's are the unconscious and unintentional effects of homosocial reproduction, stereotypes, tokenism, and the like. ${ }^{151}$ Direct evidence of these problems is difficult to find. Not only might the perpetrators not be acting with the conscious intent to impede women's progress, they are often not aware that they are perpetrators at all. Charles Lawrence describes the way this phenomenon operates with regard to unconscious racism, ${ }^{152}$ but his analysis applies equally well to unconscious sexism. "[T]acitly transmitted cultural stereotype[s]"153 about men and women operate over a lifetime and teach us about the proper roles of the sexes. But because the lessons are not taught explicitly, we are unaware of their effect on us:

[A]n individual may select a white job applicant over an equally qualified black and honestly believe that this decision was based on observed intangibles unrelated to race. The employer perceives the white candidate as "more articulate," "more collegial," "more thoughtful," or "more charismatic." He is unaware of the learned stereotype that influenced his decision. Moreover, he has probably also learned an explicit lesson of which he is very much aware: Good, law-abiding people do not judge others on the basis

${ }^{148}$ Bennun v. Rutgers State Univ., 941 F.2d 154, 181 (3d Cir. 1991) (Sloviter, C.J., dissenting from denial of petition for rehearing), cert. denied, $112 \mathrm{~S}$. Ct. 956 (1992); see also Ezold v. Wolf, Block, Schorr \& Solis-Cohen, 983 F.2d 509, 527 (3d Cir. 1992) ("These cautions against 'unwarranted invasion or intrusion' into matters involving professional judgments about an employee's qualifications for promotion within a profession inform the remainder of our analysis. ${ }^{n}$ ), cert. denied, 114 S. Ct. 88 (1993); Kunda v. Muhlenberg College, 621 F.2d 532, 548 (3d Cir. 1980) ("[I]t is clear that courts must be vigilant not to intrude into that determination, and should not substitute their judgment for that of the college with respect to the qualifications of faculty members for promotion and tenure.").

149983 F.2d at 522.

${ }^{150} I d$. at 534.

${ }^{151}$ See supra parts I.A.1, I.A.3, \& I.A.6.

152 See Lawrence, supra note 68, at 328-44.

${ }^{153}$ Id. at 343 . 
of race. Even the most thorough investigation of conscious motive will not uncover the race-based stereotype that has influenced his decision. ${ }^{154}$

Furthermore, the actors who evaluate personnel in high-level jobs may be more sophisticated about their legal responsibilities and thus more careful to avoid making any incriminating comments. Although some plaintiffs may catch their employer making statements that clearly reveal a gender-influenced decision, ${ }^{155}$ these will probably be rare occurrences.

\section{The Promise of Price Waterhouse}

An examination of recent employment discrimination cases dealing with subjective decision-making processes reveals the courts' ambivalence in this area of the law. In Price Waterhouse $v$. Hopkins, ${ }^{156}$ the Supreme Court eloquently discussed the legal relevance of sex stereotyping in proving a disparate treatment case. ${ }^{157}$ The Court seemed to be moving closer to an understanding of the subtle barriers that often keep women out of the most prestigious jobs. Ann Hopkins did not have to prove directly that Price Waterhouse's decision to deny her partnership was consciously motivated by gender. Instead, the Court held that the prevalence of sex stereotyping in the workplace made it more likely than not that "the partners reacted negatively to her personality because she is a woman." 158

Because the behavior at issue in Price Waterhouse was particularly egregious, the case was not as big a victory for upper-level plaintiffs as it appeared to be. Although the Court acknowledged that unconscious sex stereotypes can have a real effect on employment decisions, the stereotypes at work in that case were not particularly

$154 I d$.

155 Ann Hopkins was one such lucky plaintiff. Despite the fact that she was responsible for securing more contracts for Price Waterhouse than any other partnership candidate and that one project in particular had been carried out "virtually at the partner level," Ann Hopkins was denied partnership. Price Waterhouse v. Hopkins, 490 U.S. 228, 233 (1989). Fortunately, Hopkins had clear evidence that her gender influenced the decision. Several partners complained about her use of profanity, one partner suggested that she take "a course at charm school," and another called her "macho." Perhaps the most damaging evidence came from the man who told her that to improve her chances she should "walk more femininely, . . . wear make-up, have her hair styled, and wear jewelry." Id. at 235.

156490 U.S. 228.

157 See id. at 250-51.

${ }^{158}$ Id. at 258. 
subtle. ${ }^{159}$ When Ann Hopkins was told that to improve her chances for partnership she should "walk more femininely, talk more femininely, dress more femininely, wear make-up, have her hair styled, and wear jewelry, ${ }^{n 60}$ she was being held to an overtly different standard than her male colleagues. Furthermore, the main evidence in the case-sex stereotyping-is not as controversial as most of the other social and psychological phenomena outlined in Part I of this Comment. ${ }^{161}$

\section{The Reality of Ezold}

Nancy Ezold's recent suit against the Philadelphia law firm Wolf, Block, Schorr and Solis-Cohen is probably a more typical example of a modern, upper-level employment discrimination case. Unlike Ann Hopkins, the plaintiff in Price Waterhouse, Ezold was not a superstar' who clearly outshone the male candidates for partner. There was, however, a significant amount of evidence that she had been treated differently than male candidates. ${ }^{162}$ The process by which partners evaluated associates under partnership consideration was extremely subjective, with all partners, no matter how familiar they were with the associate's work, evaluating each candidate "on the basis of what [they] expect[ed] of an Associate at th[e] Associate's level of experience." 163 The district court noted evidence that stereotyping had influenced the firm's decision:

The plaintiff was criticized for being "very demanding" and was expected by some members of the Firm to be nonassertive and acquiescent to the predominately male partnership. Her failure to accept this role was a factor which resulted in her not being promoted to partner. However several male associates who had been evaluated negatively for lacking sufficient assertiveness in their demeanor were made partners. ${ }^{164}$

${ }^{159}$ See supra note 155.

160490 U.S. at 235.

${ }^{161}$ For example, in a recent survey of Fortune $1000 \mathrm{CEOs,} \mathrm{of} \mathrm{the} 80 \%$ of the respondents who acknowledged the existence of barriers keeping women from top positions, $81 \%$ (or about $65 \%$ of all respondents) named "stereotyping" and "precon-

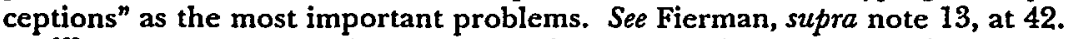

${ }_{162}$ See Ezold v. Wolf, Block, Schorr \& Solis-Cohen, 751 F. Supp. 1175, 1183, 1191 92 (E.D. Pa. 1990), rev'd 983 F.2d 509 (3d Cir. 1992), cert denied, 114 S. Ct. 88 (1993).

${ }^{163}$ Id. at 1180; see also Radford, supra note 31 , at $488 \mathrm{n} .65$ ("Studies indicate that the possibility of bias based on stereotypical notions increases when no information or only ambiguous information is available as to the actual performance of an employee.").

${ }_{164}$ Ezold, 751 F. Supp. at 1189 (emphasis omitted). 
The partner in charge of assignments told Ms. Ezold when she was hired that "it would not be easy for her at Wolf, Block because she did not fit the Wolf, Block mold since she was [among other things] a woman. ${ }^{\text {165 }}$ When Ezold brought the treatment of paralegals to the firm's attention, she was criticized for being too concerned with women's issues. A male attorney did not receive the same criticism when he brought up the issue of part-time attorneys, even though he recognized it as a women's issue. ${ }^{166}$ Furthermore, the firm had a weak sexual harassment policy, evidenced by the fact that allegations of sexual harassment against a male associate were considered so insignificant that they were not even brought to the attention of the members of the Associates Committee when they were considering him for partnership. ${ }^{167}$ Finally, one partner admitted that the inferior quality of the cases assigned to Ezold put her in an impossible situation: the chairman of the department would not assign her to complex cases, yet at evaluation time she was criticized because she had not worked on complex cases. ${ }^{168}$ The district court concluded:

The defendant promoted to partnership men having evaluations substantially the same or inferior to the plaintiff's, and indeed promoted male associates who the defendant claimed had precisely the lack of analytical or writing ability upon which Wolf, Block purportedly based its decision concerning the plaintiff. ... Such differential treatment establishes that the defendant's reasons were a pretext for discrimination. ${ }^{169}$

Despite the substantial amount of evidence in Ezold's favor, the court of appeals reversed the decision, concluding that "there is no evidence of sex discrimination here."170 Although the court denied that it was insulating the firm's subjective judgments from judicial review, ${ }^{171}$ it seemed to be doing exactly that. It ignored the traditional fact-finding function of the district court by using evaluations from all of the partners instead of limiting its analysis to only those evaluations from partners whom the district court had

${ }^{165} \mathrm{Id}$. at 1177.

${ }^{166}$ See id. at 1188 .

167 See id.

${ }^{168}$ See id. at 1178-79.

${ }^{169}$ Id. at 1191-92.

${ }^{170}$ Ezold v. Wolf, Block, Schorr \& Solis-Cohen, 983 F.2d 509, 547 (3d Cir. 1992), cert. denied, 114 S. Ct. 88 (1993).

${ }^{171}$ See id. at 527 ("[S]ubjective promotion decisions . . . are not insulated from judicial review for unlawful discrimination."). 
found to be without gender bias. ${ }^{172}$ It admitted lowering its level of scrutiny because the decision involved was a subjective promotion decision for an upper-level job. ${ }^{173}$ The court justified all of this by pointing to the fact that courts should defer to the subjective decisions of employers:

Were the factors Wolf considered in deciding which associates should be admitted to the partnership objective, as opposed to subjective, the conflicts in various partners' views about Ezold's legal analytical ability that this record shows might amount to no more than a conflict in the evidence that the district court as factfinder had full power to resolve. ${ }^{174}$

Thus, according to the Third Circuit the district court is only allowed to scrutinize employment decisions that are based on objective criteria. Whereas the employer in Watson unsuccessfully tried to argue that subjective employment decisions should be immune from disparate impact scrutiny, ${ }^{175}$ the Ezold court seemed to go even further by immunizing Wolf, Block from disparate treatment scrutiny. ${ }^{176}$

\section{Why the Lower Level of Scrutiny?}

Why do some courts shy away from scrutinizing upper-level employment decisions? One explanation may be that judges identify with the decision-makers involved:

Judges defer to the employers with whom they identify, and they uphold the kinds of selection systems from which they have benefited. When they deal with prestigious jobs, the courts show an appreciation of the apparent rationality of the employment procedures at issue and a respect for the decisionmakers involved that can only be explained by the fact that these cases confront the courts with their own world. Judges have a personal investment in traditional selection procedures on the upper level. ${ }^{177}$

${ }^{172}$ See id. at 532 n.22.

${ }^{173}$ See id. at 527.

174 Id. at 529.

${ }^{175}$ See Watson v. Fort Worth Bank \& Trust, 487 U.S. 977, 989-90 (1988).

${ }^{176}$ See Brief of Amici Curiae Fifty-Five Organizations in Support of the Petitioner at 9, Ezold v. Wolf, Block, Schorr and Solis-Cohen, 983 F.2d 509 (3d Cir. 1992) (No. 92-2013), cert. denied, 114 S. Ct. 88 (1993).

177 Bartholet, supra note 4 , at 979 . In one case concerning academic tenure, the court admitted its sympathy for the employer:

Of a hypothetical twenty equally brilliant law school graduates in a law office, one is selected to become a partner. Extensive discovery would 
Another reason for this hands-off approach is the perceived importance of the jobs at stake. Courts appear to believe that lower-level jobs are fungible, involving tasks that many people could perform, whereas upper-level jobs are more important and difficult to perform. Thus, the disruption involved in striking down a discriminatory employment system is not as worrisome when only lower-level jobs will be affected. ${ }^{178}$

The courts may also feel that their lack of expertise concerning many upper-level professions disqualifies them from scrutinizing employment decisions. ${ }^{179}$ As the Third Circuit warned in an academic tenure case, "[d]eterminations about such matters as teaching ability, research scholarship, and professional stature ... must be left for evaluation by the professionals, particularly since they often involve inquiry into aspects of arcane scholarship beyond the competence of individual judges. ${ }^{n 180}$

There may also be a concern that scrutinizing upper-level employment decisions will inevitably take too much discretion away from employers. In Ezold, for example, the district court was skeptical of Wolf, Block's requirement that associates demonstrate the ability to handle complex litigation on their own. ${ }^{181}$ In its reversal, the court of appeals scolded the lower court for questioning the firm's partnership standards instead of merely how those standards were applied. ${ }^{182}$

Another explanation may be that the courts are reluctant to scrutinize upper-level employment systems, which are usually based

reveal that the other nineteen were almost equally well qualified. Fifty junior bank officers all aspire to become a vice-president-one is selected. And, of course, even judges are plagued by the difficulty of decision in selecting law clerks out of the many equally well qualified.

Faro v. New York Univ., 502 F.2d 1229, 1232 (2d Cir. 1974).

${ }^{178}$ See Bartholet, supra note 4, at 956-57. Bartholet notes that:

Courts may have felt fairly comfortable with the more radical implications of Griggs for lower-level jobs because there jobs did not seem particularly important. On the upper level, however, where courts feel that the quality of performance really matters, they may be reluctant to interfere with traditional selection methods.

Id. at 957.

${ }^{179}$ See id. at 979 .

${ }^{180}$ Kunda v. Muhlenberg College, 621 F.2d 532, 548 (3d Cir. 1980).

${ }^{181}$ See Ezold v. Wolf, Block, Schorr \& Solis-Cohen, 751 F. Supp. 1175, 1188 (E.D.

Pa. 1990), rev'd, 983 F.2d 509 (3d Cir. 1992), cert. denied, 114 S. Ct. 88 (1993).

182 See Ezold v. Wolf, Block, Schorr \& Solis-Cohen, 983 F.2d 509, 527-28 (3d Cir.

1992), cert. denied, 114 S. Ct. 88 (1993). 
on subjective criteria, because they fear that there are no alternative objective systems with which to replace them. ${ }^{183}$ This fear is especially apparent in disparate impact cases. With lower-level cases, like Griggs, the employer can avoid being forced into a quota system by simply adopting a job-related objective system that does not have an adverse impact on a protected group. ${ }^{184}$ But with upper-level cases, in which subjectivity is often required, some fear that a court decision striking down an employer's subjective system would force the employer to adopt quotas. ${ }^{185}$

Finally, the courts may apply a lower level of scrutiny to upperlevel cases because those cases are normally brought as individual disparate treatment cases. ${ }^{186}$ It is relatively easy to argue that subtle, unconscious differences in the way an employer treats men and women are having a real effect when one can look at large numbers and point to a resulting statistical disparity. Disparate impact plaintiffs and systemic disparate treatment plaintiffs both benefit from this kind of evidence. When the plaintiff can show that a pattern has developed, the employer's explanations are less likely to be believed. Thus, when the employer in Stender v. Lucky Stores, Inc. ${ }^{187}$ explained that the disparity between the number of men and women in certain positions in its stores was a result of women's lack of interest in those positions, the court was skeptical. ${ }^{188}$ When looking at an isolated case, on the other hand, the employer's explanation may seem to make perfect sense. Thus, Wolf, Block's declaration that the reason for Nancy Ezold's failure to be promoted to partnership was her lack of legal analytical ability was not particularly suspicious. ${ }^{189}$ If Wolf, Block had tried to use an explanation like this in the face of a large number of seemingly qualified women being denied partnership at a much higher rate of

${ }^{183}$ See supra notes $126-27$ and accompanying text.

${ }^{184}$ See Griggs v. Duke Power Co., 401 U.S. 424, 436 (1971) (prohibiting the use of testing that has a disparate impact on a protected group and does not provide a measure of job performance).

${ }^{185}$ In Watson v. Fort Worth Bank \& Trust, 487 U.S. 977 (1988), for example, the defendant worried that the only way to avoid liability under a disparate impact theory of liability would be to adopt numerical quotas. See id. at 989.

${ }^{186}$ See supra notes $137-45$ and accompanying text.

187803 F. Supp. 259 (N.D. Cal. 1992).

${ }^{183}$ See id. at 326. But see EEOC v. Sears, Roebuck \& Co., 839 F.2d 302, 322 (7th Cir. 1988) (accepting Sears's contention that the disparity between the number of men and women in commission sales positions was the result of women's lack of interest in those positions).

${ }^{189}$ See Ezold, 983 F.2d at 517-18. 
frequency than men, which is the typical scenario in a pattern or practice case, the court might not have been quite so amenable.

\section{Why a Lower Level of Scrutiny for Upper-Level Employment Decisions Is Inadequate}

As discussed in Part I, the highly subjective nature of most upper-level employment decisions makes them even more susceptible to unconscious biases than lower-level employment decisions. ${ }^{190}$ Thus, when choosing the best widget assembler, an employer will probably rely on the objective qualification of widgets assembled per minute and never have the opportunity to let unconscious biases affect the employment decision. When choosing partners in a law firm or granting tenure in a university, however, it will be much easier for an employer to let unintentional stereotypes cloud the decision. ${ }^{191}$

If this unconscious sexism affected only employers, the courts' tendency to examine upper-level employment decisions with less scrutiny than lower-level employment decisions would not be quite so problematic. But unconscious sexism infects the rest of society as well. Lawrence's discussion of the universality of racism in our society probably could be applied to sexism as well:

Americans share a common historical and cultural heritage in which racism has played and still plays a dominant role. Because of this shared experience, we also inevitably share many ideas, attitudes, and beliefs that attach significance to an individual's race and induce negative feelings and opinions about nonwhites. To the extent that this cultural belief system has influenced all of us, we are all racists. ${ }^{192}$

Similarly, the perceptions of judges and jury members are likely to be at least somewhat influenced by unconscious sexism. There is no reason to think that women will be infected with unconscious sexism to a significantly less extent than men. As one legal scholar has noted, "both men and women have been imbued with the notion

${ }^{190}$ See supra notes 73-80 and accompanying text.

${ }^{191}$ It is not surprising that Charles Lawrence, when discussing the role that unconscious racism can play in an employment decision, uses upper-level jobs and subjective decision-making criteria in his examples. The jobs he picks for his hypothetical situations are doctor and lawyer. The criteria his hypothetical employers use are "articulate," "collegial," "thoughtful," and "charismatic." Lawrence, supra note 68 , at 343 .

${ }^{192}$ Id. at 322. 
that there is an inherent conflict between femininity and competence." 193 Given this context of widespread, unconscious sexism, a low level of scrutiny for upper-level employment decisions is inadequate to carry out the mandate of Title VII. In fact, the susceptibility of subjective employment decisions to the influence of unconscious biases makes close judicial scrutiny essential. When judges use a low level of scrutiny, it is even easier for them to accept employers' explanations for their decisions at face value. After all, judges are influenced by the same unconscious biases that influence employers, and chances are that neither side is aware of the influence.

The unconscious sexism of judges, combined with an extremely low level of scrutiny, may explain how the court of appeals came to such a drastically different conclusion than the district court in Ezold. The district court judge seemed aware of many of the subtle factors that tend to work against women in upper-level jobs and was able to place Ezold's individual stories in the larger context of women workers as a group. He discussed gender stereotyping, ${ }^{194}$ the fact that Ezold was held to a higher standard than male associates, ${ }^{195}$ and the inferiority of her work assignments ${ }^{196}$ as examples of the way Ezold received different treatment than her male counterparts. Thus, instead of ignoring the unconscious sexism that seemed to have pervaded Ezold's workplace, the district court judge applied traditional Title VII scrutiny to Wolf, Block's decision and found it to be discriminatory. ${ }^{197}$

The court of appeals, on the other hand, applied a lower level of scrutiny to the case. ${ }^{198}$ As a result, the unconscious sexism that seemed to influence Wolf, Block's decision may have influenced the Third Circuit's decision as well. A shortcoming in legal analytical skills appeared to be a reasonable explanation for a denial of partnership. ${ }^{199}$ If Wolf, Block was not aware that subtle forms of sexism inhibited Ezold's chances for partnership, there is no reason

193 Taub, supra note 30 , at 356.

194 See Ezold v. Wolf, Block, Schorr \& Solis-Cohen, 751 F. Supp 1175, 1189 (E.D.

Pa. 1990), rev'd, 983 F.2d 509 (3d Cir. 1992), cert. denied, 114 S. Ct. 88 (1993).

195 See id. at 1184-85.

${ }^{196}$ See id. at 1178-79.

${ }^{197}$ See id. at $1190-92$.

${ }^{198}$ See generally Ezold v. Wolf, Block, Schorr \& Solis-Cohen, 983 F.2d 509 (3d Cir. 1992), cert. denied, 114 S. Ct. 88 (1993); see also supra notes $170-76$ and accompanying text.

${ }^{199}$ See Ezold, 983 F.2d at 533. 
to expect that a court affected by the same sexism would be any more perceptive. This is especially true when that court is applying an artificially lowered level of judicial scrutiny. Thus, whereas the district court carefully examined the evidence in a broader context, remaining aware that unconscious sexism could affect the decision of a virtually all-male partnership, the court of appeals seemed to go out of its way to deny that unconscious sexism played any part in the decision. ${ }^{200}$

For a variety of reasons, then, a lower degree of scrutiny for upper-level employment discrimination cases will make it nearly impossible for a plaintiff to succeed. The fact that upper-level cases typically must be brought as individual disparate treatment cases will prevent courts from seeing the subtle barriers outlined in Part I as patterns and will make it more likely that an employer's articulated reason for the decision will be believed. The high likelihood that the fact-finder will be influenced by the same unconscious biases as the employer means that the plaintiff will need to have dramatic evidence of overt discrimination to convince the fact-finder that discrimination occurred. Consequently, many cases of upper-level discrimination will go undetected and unremedied.

\section{Suggestions for Change}

To eliminate the glass ceiling in the United States, courts must change the way they approach upper-level employment discrimination cases. The psychological and sociological factors that keep women in less prestigious jobs will not disappear spontaneously. The courts must therefore find an effective way to remedy the discrimination that those factors inevitably cause. At a time when global competitiveness is essential to the health of the U.S. economy, we can no longer afford to live with a system that drains organizational productivity. ${ }^{201}$ Before outlining a proposal

${ }^{200}$ The court of appeals found nothing problematic about Wolf, Block's practice of giving weight to the "comments of partners who had little contact and perhaps knew nothing about an associate beyond the associate's general reputation." Id. at 532. The court concluded that this practice was not problematic because " $[t]$ here is no evidence that [it] . . . was not applied equally to female and male associates." Id. The court reached this conclusion despite the fact that industrial psychologists agree that evaluations by those with little knowledge of the candidate are highly susceptible to the influence of unconscious biases. See CAScio, supra note 76, at 66; Radford, supra note 31 , at 488 n.65.

${ }^{201}$ See Uma Sekaran \& Frederick T.L. Leong, Introduction to WOMANPOWER: Managing in Times of Demographic Turbulence at ix, xi (Uma Sekaran \& 
for applying increased judicial scrutiny, however, it is useful to demonstrate why, despite some courts' hesitations, such scrutiny is both necessary and appropriate.

\section{A. An Exemption from Scrutiny Is Not Necessary}

Courts and commentators point to a number of factors that might explain judicial reluctance to scrutinize upper-level employment decisions. A careful examination of these factors, however, reveals that none provides sound justification for the courts' continued reluctance to exercise the full scope of their judicial authority. The courts can overcome these perceived stumbling blocks and develop schemes that will facilitate their review of upperlevel cases without unnecessarily impeding employer discretion. One factor that has apparently deterred judges from fully scrutinizing high-level employment decisions is judges' close identification with the employers involved. As Bartholet points out, however, this lack of judicial distance is no excuse for judges to shirk their Title VII duties in the upper-level employment context: "In dealing with lower level jobs, the courts have had enough distance to weigh the social cost of racial exclusion against the need for traditional systems... Judges must develop this same analytic distance in looking at upper level selection systems. ${ }^{202}$

A second factor that courts have invoked to avoid scrutinizing upper-level decisions is their professed lack of expertise in making employment decisions. ${ }^{203}$ First, a lack of expertise should present no more of a problem for upper-level cases than for lower-level cases. In fact, judges are more likely to be familiar with the professional world of law partnerships and academia than with the blue-collar world of factories and construction crews. ${ }^{204}$ Second, even if lack of expertise did present greater problems in the upperlevel employment context, the difficulty of the factual inquiry would still not justify an exemption from scrutiny. Courts are frequently called upon to make complex, technical, factual inquiries in a

Frederick T.L. Leong eds., 1992) (" $[$ E]ffective solutions [must] be generated to enhance organizational productivity . . . at a time when remaining competitive in the global market is of critical importance to the United States.").

202 Bartholet, supra note 4, at 980.

${ }^{203}$ See, e.g., Kunda v. Muhlenberg College, 621 F.2d 532, 548 (3d Cir. 1980) (noting that, in the context of tenure decisions for college professors, judgments about teaching ability, research scholarship, and professional stature are "beyond the competence of individual judges").

${ }_{204}$ See Bartholet, supra note 4, at 979-80. 
variety of contexts. In other areas of the law, expert-witness testimony is commonly used to educate fact-finders. ${ }^{205}$ Lack of expertise should be no more of a hindrance to the courts in employment discrimination cases than in other areas of law.

A third, but equally unconvincing rationale used to justify the courts' deference to upper-level employment decisions is the belief that upper-level jobs are more important and less fungible than lower-level jobs. ${ }^{206}$ The importance of these jobs, however, hardly seems to justify the protection of systems that allocate them in a discriminatory manner. If these jobs truly are more important, then every qualified individual should have an equal opportunity to compete for them based on individual merit. The fact that "courts feel that the quality of performance really matters ${ }^{207}$ in upperlevel jobs does not justify leaving the assessment of employees' performance to potentially bias-ridden systems. Rather, it suggests a compelling reason for courts to scrutinize such decisions to ensure that they are founded on meaningful criteria.

Finally, the courts are not justified in their concern that scrutinizing upper-level employment decisions will take all decisionmaking power away from employers. ${ }^{208}$ This concern does not keep courts from scrutinizing lower-level decisions, and likewise should not keep them from scrutinizing upper-level decisions. Even if this concern were uniquely applicable to upper-level decisions, it could still be overcome. Some courts wrongly assume that there are no viable alternatives available to replace overly subjective decisionmaking systems for upper-level positions. ${ }^{209}$ These courts fail to recognize that subjectivity is a matter of degree. The fact that some subjectivity is required when making upper-level employment decisions does not imply that all elements of the subjective system play a legitimate role in a fair, unbiased evaluation system. Judicial scrutiny can screen out-and induce employers to screen outunnecessarily subjective evaluations while preserving legitimate merit-based criteria. As outlined below, there are numerous ways

${ }^{205}$ See FED. R. EVID. 702 advisory committee's note ("An intelligent evaluation of facts is often difficult or impossible without the application of some scientific, technical, or other specialized knowledge. The most common source of this knowledge is the expert witness, although there are other techniques for supplying it.").

${ }^{206}$ See Bartholet, supra note 4, at 957.

${ }^{207}$ Id.

${ }^{203}$ See supra notes $126-27$ and accompanying text.

${ }^{209}$ See, e.g., Ezold v. Wolf, Block, Schorr \& Solis-Cohen, 983 F.2d 509, 527 (3d Cir. 1992), cert. denied, 114 S. Ct. 88 (1993); see also supra note 126. 
to scrutinize subjective employment judgments while still preserving a significant amount of employer discretion.

\section{B. Increased Judicial Scrutiny for Upper-Level Cases}

\section{Employment Discrimination Law Should Be Applied in a Context-Specific Fashion}

Understanding that not all subjective decision-making systems are alike is the key to enabling courts to scrutinize upper-level employment decisions effectively, yet leave employers' legitimate interests intact. Although some amount of subjectivity is required when choosing employees for upper-level jobs, the courts need not accept all such subjective decision-making systems at face value with little or no judicial scrutiny. Thus, the courts should take into account the arbitrariness of the employer's system before deciding how much deference the employer's subjective judgment deserves. Only employers who can prove that their decision-making processes are neither arbitrary nor overly subjective should receive the low level of scrutiny that characterizes many upper-level employment discrimination cases today. ${ }^{210}$ All other employers should receive traditional Title VII scrutiny. By taking the context in which the employment decision was made into account in order to determine which level of scrutiny should be applied, courts can help make the three traditional theories of employment discrimination liability more amenable to upper-level claims.

Under a context-specific application of employment discrimination theory, ${ }^{211}$ the employer would carry the burden of persuasion in demonstrating to the fact-finder that its decision-making system is not arbitrary or overly subjective. Only if the employer succeeds in this effort would the lower level of scrutiny that the court of appeals applied in the Ezold case be available. ${ }^{212}$ In individual disparate treatment cases, ${ }^{213}$ this lower level of scrutiny would

${ }^{210}$ See supra notes 170-76 and accompanying text.

${ }^{211}$ A context-specific application of discrimination law would vary the level of judicial scrutiny utilized in a case based on the context in which that decision was made. For example, a decision made in an atmosphere of rampant sex stereotyping and highly vague and subjective evaluation criteria would receive the traditional level of Title VII scrutiny. A decision using well-defined and structured evaluation instruments, made in an atmosphere that stresses the importance of unbiased decision-making, would receive a lower level of scrutiny.

${ }^{212}$ See supra notes 170-76 and accompanying text.

${ }^{213}$ Because upper-level employment discrimination cases are usually brought 
translate into a presumption that the employer's articulated reason was not a pretext for discrimination. Since the employer already would have proven that the decision-making system in place was as structured and objective as possible, the courts could more readily accept the employer's representations that its employment decisions were founded on merit, not bias. If the employer were able to demonstrate that it had eliminated excessively subjective criteria, the plaintiff, in order to prevail, would have to present "obvious or manifest" evidence that the employer's "subjective standard was unequally applied before a court [could] find pretext." ${ }^{214}$

If the employer were unable to prove that its decision-making system was not arbitrary or overly subjective, the court would apply traditional Title VII scrutiny, much like the district court did in Ezold. The arbitrary system in place would become one piece of evidence that the plaintiff could use to establish pretext. Given that the social and psychological factors at work in upper-level employment decisions ${ }^{215}$ are exacerbated by overly subjective decisionmaking systems, ${ }^{216}$ it would be illogical to assume that the employer's decision was unbiased. ${ }^{117}$ Thus, instead of insisting that the plaintiff's evidence of pretext be "obvious or manifest," ${ }^{218}$ the court would require the plaintiff to prove pretext by only a preponderance of the evidence, ${ }^{219}$ the traditional evidentiary burden in

under the individual disparate treatment theory, this analysis will focus on the way courts should adjust their individual disparate treatment analysis according to the arbitrariness of the employer's decision-making system. For a discussion of the reasons that plaintiffs in upper-level cases usually use the individual disparate treatment theory, see supra notes $137-44$ and accompanying text. For a discussion of how courts could adjust disparate impact analysis and systemic disparate treatment analysis based on the arbitrariness of the employer's decision-making system, see infra note 220.

214 Ezold v. Wolf, Block, Schorr \& Solis-Cohen, 983 F.2d 509, 534 (3d Cir. 1992), cert. denied, $114 \mathrm{~S}$. Ct. 88 (1993). It is interesting to note that, earlier in its opinion, the court stated that the evidentiary burden on the plaintiff would be to prove "by a preponderance of the evidence" that the employer's articulated reason was a pretext for discrimination. Id. at 522. The court changed its standard to "obvious or manifest" only after noting that the decision at issue was based on subjective factors. Id. at 534 .

215 See supra part I.A.

${ }^{216}$ See supra part I.B.

${ }^{217}$ Generally, courts presume that the employer's articulated reason is valid until the plaintiff proves otherwise. See, e.g., McDonnell Douglas Corp. v. Green, 411 U.S. 792,805 (1973). A context-specific proposal would eliminate this presumption when the employer fails to prove that its selection process was not arbitrary or overly subjective.

${ }^{218}$ Ezold, 983 F.2d at 534.

${ }^{219}$ See Texas Dep't of Community Affairs v. Burdine, 450 U.S. 248, 253 (1981) (noting that, once the defendant articulates a legitimate, nondiscriminatory reason for 
individual disparate treatment cases. ${ }^{220}$ This evidentiary scheme would allow courts to overcome the individual disparate treatment theory's focus on intent, an approach that fails to address unconscious discrimination. ${ }^{221}$

\section{Factors To Consider}

These distinctions between overly subjective systems and permissibly subjective systems invite a difficult question: What factors should courts consider when determining which employers receive traditional Title VII scrutiny and which employers receive the special lower level of scrutiny? The courts are not without guidance in identifying these factors. A commonsense understanding of the social and psychological factors that affect upper-level employment decisions, ${ }^{222}$ the EEOC's guidelines on employee selection procedures, ${ }^{223}$ and the recommendations of industrial psychologists $^{224}$ all suggest criteria that the courts can use to distinguish valid decision-making systems from arbitrary, potentially discriminatory ones. These criteria can help the courts determine which subjective decisions deserve deference and which demand careful scrutiny.

One factor the courts could consider is whether the employer utilizes a system that monitors the distribution of work assignments. As the Ezold case demonstrates, because women are often not given

rejecting the plaintiff, "the plaintiff must then have an opportunity to prove by a preponderance of the evidence that the legitimate reasons offered by the defendant were not its true reasons, but were a pretext for discrimination").

${ }^{220}$ Although this section focuses on individual disparate treatment cases, a similar analysis could be used for disparate impact cases and systemic disparate treatment cases. One approach in disparate impact cases would be to allow a plaintiff to establish a claim by showing that: (1) the employer has failed to justify the subjectivity of its decision-making process, raising a presumption of bias; and (2) the system has a disproportionately negative effect on women. Another possible approach in disparate impact cases would entitle the employer to a more lenient standard of business necessity depending on the employer's ability to prove that its system was not unnecessarily arbitrary. See supra notes 106-07 and accompanying text (noting different standards of business necessity). Finally, in systemic disparate treatment cases, a plaintiff who could show that her employer's decision-making system was likely to be influenced by biases could use this as evidence of a pattern or practice of discrimination.

${ }^{221}$ See, e.g., Lawrence, supra note 68, at 323 (noting, in the equal protection context, that "requiring proof of conscious or intentional motivation as a prerequisite to constitutional recognition that a decision is race-dependent ignores much of what we understand about how the human mind works").

222 See supra part I.A.

${ }^{223}$ See 29 C.F.R. § 1607 (1993).

${ }^{224}$ See, e.g., CAScio, supra note 76 , at $28-30$. 
equally challenging assignments, they are not given the same chance as men to demonstrate their skills or to develop new expertise. ${ }^{225}$ This disparity is more likely to occur when assignments are distributed in an informal, unmonitored manner. Courts should therefore look for employers who have devised formal, structured systems to monitor the allocation of work assignments. Such systems allow employers to track the importance and complexity of the work given to each employee in addition to an individual employee's opportunities for exposure to influential decisionmakers. These monitoring mechanisms would afford employers a more objective basis on which to assess whether they have evaluated each employee based on demonstrated ability rather than preconceived expectations of how certain types of workers will perform.

Another factor to consider when determining whether the employer's decision-making process has a significant risk of bias is the extent to which gender stereotyping pervades the workplace. ${ }^{226}$ When stereotyping runs rampant in the workplace, it is probably safe to presume that it will have some effect on subjective judgments about women's performance and capabilities. ${ }^{227}$ Thus, courts should consider evidence concerning the extent to which stereotyping has influenced the decision-making process when determining which level of scrutiny an employer's decisions deserve. This evidence can take the form of expertwitness testimony, ${ }^{228}$ which was utilized in Price Waterhouse, ${ }^{229}$ or simply testimony of the parties and other employees who can describe the level of stereotyping that they observed in the workplace.

${ }^{225}$ For Nancy Ezold, the problem of inequitable work assignments continued even after she brought it to the attention of the partner responsible for assigning work in her department and after that partner promised to correct the problem. She was assigned primarily small civil matters and was able to work with only a limited number of partners. On one occasion, although Ezold was the only associate to volunteer for a particular project, within an hour the assigning partner reassigned it to a male associate without any explanation. See Ezold v. Wolf, Block, Schorr \& Solis-Cohen, 751 F. Supp. 1175, 1178 (E.D. Pa. 1990), rev'd, 983 F.2d 509 (3d Cir. 1992), cert. denied, 114 S. Ct. 88 (1993).

${ }^{226}$ See supra part I.A.3.

${ }^{227}$ See Price Waterhouse v. Hopkins, 490 U.S. 228, 251 (1989) (noting that stereotyping can be used as evidence to show that discrimination played a part in an employment decision).

${ }_{228}$ See supra note 205 and accompanying text.

${ }^{229}$ See 490 U.S. at 255-56 (accepting the testimony of a social psychologist who discerned sex stereotyping in the partners' evaluations of the plaintiff, and rejecting the defendant's characterization of that testimony as "gossamer evidence"). 
There are a number of steps an employer can take to reduce the level of unnecessary subjectivity in a subjective evaluation process. All of these steps should be factors that the court takes into account when deciding whether the employer's decision-making process is likely to be free from bias. One way an employer can reduce the level of subjectivity is to allow only those who are truly familiar with a candidate's performance to make employment decisions about that candidate. Industrial psychologists have warned that unconscious biases are more likely to be expressed when the evaluator has not had an adequate opportunity to observe the candidate. ${ }^{230}$ For this reason, the decision-maker should ideally be the candidate's supervisor or someone else who has had the opportunity to work directly with the candidate. ${ }^{231}$ If this is not possible, the decisionmaker should at least be given primary sources to evaluate, such as examples of the candidate's actual work product, as opposed to only secondary sources, such as evaluations written by others.

Employers can also reduce unnecessary subjectivity by taking a variety of steps to eliminate vagueness in the evaluation process itself. First, the employer can train evaluators to ensure that they use the same standards and techniques. The EEOC guidelines suggest that this training should include an explanation of the factors to be taken into account, clear definitions of all terms and rating scales, and techniques to recognize and eliminate the effects of stereotyping and biases. ${ }^{232}$ Second, all evaluations should be in writing and preserved in the candidate's personnel file in the event of a future disagreement. Finally, employers can reduce unnecessary subjectivity by allowing several people to view each candidate's work product. This could be accomplished either by establishing a formal committee or by a less formal but consistently applied practice of seeking second and third opinions before important employment decisions are made. Thus, the employer in Gillespie $v$. Wisconsin, ${ }^{233}$ whose test included a detailed grading system, established rating criteria, well-trained graders, and a thorough

${ }^{250}$ See CAscio, supra note 76, at 66.

${ }^{231}$ See id. at 77 (noting that "raters must have direct experience with, or firsthand knowledge of, the individual to be rated").

${ }^{232}$ See 29 C.F.R. $\$ 1607.14$ (B)(2) (1993) ("In view of the possibility of bias in subjective evaluations, supervisory rating techniques and instructions to raters should be carefully developed." ); CASCIO, supra note 76, at 77 (suggesting that raters be "trained in the techniques of rating").

233 771 F.2d 1035 (7th Cir. 1985), cert. denied, 474 U.S. 1083 (1986). 
validation test, ${ }^{234}$ would be entitled to substantially more deference than the employer in Stender v. Lucky Stores, Inc., ${ }^{235}$ whose employment decisions were made by store managers with no practical constraints on discretion using unwritten criteria that were both ambiguous and subjective. ${ }^{236}$

A number of other factors can also be considered as evidence that an employer has significantly reduced the risk of biased employment decisions. Efforts to advertise job openings and publicize details of the selection criteria indicate that an employer has attempted to make it easier for all candidates to compete with the same information. The courts should also look for decisionmaking bodies that are as diverse as possible; all-male committees may be less cognizant of latent gender biases than committees composed of both men and women. Also, in fields in which informal social networks can be important, the courts should recognize companies that attempt to reduce women's disadvantages in this area. Although companies neither can nor should eliminate spontaneous sex-segregated socializing, company-sponsored social events that are open and attractive to all can ensure that all employees have opportunities to interact socially with some of the more influential players, who remain predominantly male.

\section{Ezold as a Case in Point}

Applying the context-specific disparate treatment approach to a concrete upper-level employment controversy demonstrates the proposal's practical operation. It is thus informative to outline the analysis that the court would have followed had it followed this approach in the Ezold ${ }^{237}$ case. Once Ezold proved a prima facie case of discrimination, Wolf, Block would then carry the burden of persuasion in demonstrating that its partnership selection system was not likely to be influenced by bias. In its effort to meet this burden, Wolf, Block could point to its reasonably well-structured and formal evaluation process, which included written evaluations and evaluation forms that explicitly described the characteristics to be judged and the meaning of each possible grade.

${ }^{234}$ See id. at 1037-39.

235803 F. Supp. 259 (N.D. Cal. 1992).

${ }^{296}$ See id. at 331 .

237751 F. Supp. 1175 (E.D. Pa. 1990), rev'd, 983 F.2d 509 (3d Cir. 1992), cert. denied, 114 S. Ct. 88 (1993). 
Ezold, on the other hand, could point to a number of other factors that make it likely that Wolf, Block's system was influenced by gender bias. First, there was a substantial amount of evidence that she was not given the same kind of work assignments as male associates. ${ }^{238}$ Her assignments were primarily small matters, she had relatively little contact with partners in her department, and the assignment process was largely informal and unsupervised. ${ }^{239}$ Second, all partners, regardless of the extent of their familiarity with the associate's work, were expected to complete evaluations of all associates, reducing the likelihood that their evaluations represented legitimate performance-based assessments and increasing the likelihood that they represented unfounded impressions. ${ }^{240}$ Third, Ezold could point to evidence of sex stereotyping at Wolf, Block. During the hiring process, a male partner told Ezold that it would not be easy for her at Wolf, Block because she was, among other things, a woman. ${ }^{241}$ Furthermore, when Ezold expressed concern about the treatment of the firm's paralegals, who were virtually all female, she was criticized for being too involved in women's issues. ${ }^{242}$ In contrast, when a male attorney brought up the issue of part-time attorneys, which even he admitted was "well known to be a women's issue," there was no similar criticism. ${ }^{243}$ Ezold was criticized for being too assertive and demanding, whereas several male associates received negative evaluations for not being assertive enough. ${ }^{244}$ Finally, top decision-makers at the firm did not view the fact that a male associate had generated numerous sexual harassment complaints from secretaries and paralegals as relevant to that associate's eligibility for partnership. ${ }^{245}$

${ }^{233}$ See id. at 1178-79.

${ }^{239}$ See id.

${ }^{240}$ See id. at 1180; see also supra notes 230-31 and accompanying text.

211 See 751 F. Supp. at 1177.

242 See id. at 1188 .

243 Id.; see also Rhode, supra note 3, at 1191 ("In corporate cultures, 'making too much of the "woman issue" carries substantial professional risk. As a consequence, female executives have often treated the subject as 'taboo,' which perpetuates the attitudes giving rise to the 'woman's issue' in the first instance." (footnotes omitted)).

${ }^{244}$ See 751 F. Supp. at 1189.

${ }^{245}$ See id. at 1188. The Chairman of the Associates Committee testified that one incident, in which the associate allegedly "touched and flirted in an unwelcome fashion" with a secretary, was not "relevant to considerations of whether [he] was an acceptable candidate for partnership," even though the Chairman did not find the associate's account of the incident to be credible. Consequently, the Chairman did not report the incident to the Associates Committee. Id. 
Based on this evidence, it seems likely that the fact-finder would determine that Wolf, Block had not met its burden in demonstrating that its decision-making system was likely to be free from bias. Thus, the artificially low level of scrutiny that the court of appeals applied would be inappropriate. ${ }^{246}$ Instead, Wolf, Block's decision not to admit Ezold into the partnership would receive normal Title VII scrutiny. Rather than requiring Ezold to come forward with evidence that makes it "obvious or manifest" that she was treated differently than male associates, ${ }^{247}$ the context-specific disparate treatment approach would require Ezold to prove her case only by a preponderance of the evidence-the traditional evidentiary burden placed on plaintiffs in individual disparate treatment cases. ${ }^{248}$

\section{A Legal Incentive to Improve the Decision-Making Process}

Giving employers a legal incentive to develop decision-making procedures that are less likely to be influenced by bias is not without precedent. For example, courts have used a similar approach in addressing the problem of sexual harassment. When determining an employer's liability for one employee's sexual harassment of another employee, courts consider whether the employer has established a grievance procedure for, and a company policy against, sexual harassment. ${ }^{249}$ If an employer has taken adequate steps to redress and prevent the recurrence of sexual harassment, courts reduce or even completely eliminate that employer's liability for the sexual harassment of its employee. ${ }^{250}$

${ }^{246}$ See supra notes $170-76$ and accompanying text.

${ }^{247}$ Ezold v. Wolf, Block, Schorr \& Solis-Cohen, 983 F.2d 509, 534 (3d Cir. 1992), cert. denied, 114 S. Ct. 88 (1993).

${ }^{248}$ The Ezold district court applied this standard. See 751 F. Supp. at 1191; see also Texas Dep't of Community Affairs v. Burdine, 450 U.S. 248, 253 (1981) (establishing preponderance of the evidence standard in individual disparate treatment cases).

${ }^{249}$ See, e.g., Meritor Sav. Bank v. Vinson, 477 U.S. 57, 72 (1986) (noting that these considerations are "plainly relevant" to determination of liability); Karibian v. Columbia Univ., 14 F.3d 773, 779 (2d Cir.) (applying Meritor standard of employer liability), cert. denied, 114 S. Ct. 2693 (1994); Sauers v. Salt Lake County, 1 F.3d 1122, 1125 n.3 (10th Cir. 1993) (same); Davis v. Tri-State Mack Distribs., Inc., 981 F.2d 340, 343 n.1 (8th Cir. 1992); Waltman v. International Paper Co., 875 F.2d 468, 478 (5th Cir. 1989) (same); Lipsett v. University of Puerto Rico, 864 F.2d 881, 899-900 (1st Cir. 1988) (same).

${ }^{250}$ The Meritor Court implied that when an employer has a strong policy against sexual harassment and the plaintiff, for no apparent reason, fails to resort to the employer's established grievance procedure, the employer may be completely insulated from liability. See 477 U.S. at 72-73. 
In this way, the courts give employers an incentive to take prophylactic measures to prevent harassment.

Employment law is not the only area in which courts reward defendants by granting greater deference to institutions with proper procedures in place. In corporate law, the business judgment rule performs a similar function. When determining whether a decision made by a corporation's directors or officers fulfills the duty of care, the court examines the process on which the decision-makers relied in reaching the decision. When the court is convinced that the decision-makers have taken adequate steps to eliminate selfinterest, have considered all relevant factors, and have exercised an informed, expert judgment, the court reduces the scrutiny with which it reviews the substance of the decisions, requiring that the decision be only rational as opposed to reasonable. ${ }^{251}$ The business judgment rule thus deters arbitrary, haphazard decisions by rewarding corporate directors who follow proper decision-making methods.

Similarly, the courts can induce employers to rely only on relevant employment-related factors rather than on unfounded biases by establishing a Title VII analysis that affords greater deference to employers willing to minimize the impact of bias by implementing structured, controlled processes. The courts' current application of Title VII in the upper-level employment context provides exactly the opposite incentive: the more subjective and arbitrary (and thus potentially bias-ridden) a decision-making system is, the more likely some courts are to defer to the judgments that emerge from this system. ${ }^{252}$ By rewarding more disciplined,

The EEOC also emphasizes the relevance of preventive techniques in its Guidelines on Discrimination Because of Sex:

Prevention is the best tool for the elimination of sexual harassment. An employer should take all steps necessary to prevent sexual harassment from occurring, such as affirmatively raising the subject, expressing strong disapproval, developing appropriate sanctions, informing employees of their right to raise and how to raise the issue of harassment under title VII, and developing methods to sensitize all concerned.

29 C.F.R. § 1604.11(f) (1993).

${ }^{25 l}$ See American LaW InST., Principles of Corporate Governance: ANAlysis AND RECOMMENDATIONS \$ 4.01(c) (Proposed Final Draft 1992); see also Smith v. Van Gorkom, 488 A.2d 858, 872 (Del. 1985) (stating that the "business judgment rule exists to protect and promote the full and free exercise of the managerial power" granted to directors).

${ }^{252}$ See, e.g., Ezold v. Wolf, Block, Schorr \& Solis-Cohen, 983 F.2d 509, 529-30 (3d Cir. 1992) (noting that the district court should not have exercised its fact-finding function to make determinations about Ezold's legal analytical ability in face of 
principled evaluation methods with greater judicial deference, the courts can encourage employers to eliminate unnecessary subjective elements from their processes.

\section{Responses to Potential Criticism}

Asking courts to distinguish between employers with arbitrary and nonarbitrary decision-making systems should not be problematic. First, courts already make this distinction when lower-level jobs are at stake. In those cases, courts seem perfectly capable of determining whether the subjectivity in a decision-making system is necessary to select the best employees or whether it leads to arbitrary, unfounded decisions. ${ }^{253}$ Second, courts are called upon to make close factual judgments of this kind in many other types of cases as well. In reviewing corporate decision-making, for example, the factfinder must decide whether the corporation's stated reasons are mere post hoc rationalizations to mask more arbitrary actions, or whether the surrounding facts lend the decision-makers an aura of credibility. ${ }^{254}$ Neither the necessarily fact-intensive nature of this inquiry nor the elusiveness of decisive evidence has deterred courts from adjudicating which corporate decision-making processes violate the law. Third, the burden-shifting principles of this context-specific Title VII analysis make it a judicially manageable approach, even in close cases. The employer would bear the burden of persuasion on the validity of its decision-making system, leading to a traditional level of Title VII scrutiny whenever the employer cannot demonstrate that it has reduced the level of bias in its decision-making process.

Another potential concern may be that providing a lower level of scrutiny to employers in certain employment discrimination cases

conflicting evidence, because factors that Wolf, Block considered were subjective instead of objective), cert. denied, 114 S. Ct. 88 (1993); Bennun v. Rutgers State Univ., 941 F.2d 154, 181 (3d Cir. 1991) (Sloviter, C.J., dissenting from denial of petition for rehearing) (stating that the court should not review subjective academic tenure and promotion decisions unless "the evidence of discriminatory action is unmistakable"), cert. denied, 112 S. Ct. 956 (1992); Kunda v. Muhlenberg College, 621 F.2d 532, 548 (3d Cir. 1980) (stating that the court should leave subjective determinations to professionals familiar with the field, unless such determinations are clearly discriminatory).

${ }_{253}$ See supra note 122 and accompanying text.

${ }^{254}$ See supra note 251 and accompanying text; see also Van Gorkom, $488 \mathrm{~A} .2 \mathrm{~d}$ at 872 (stating that the business judgment rule presumes that in making a business decision, "the directors of a corporation acted on an informed basis, in good faith and in the honest belief that the action taken was in the best interest of the company"). 
will allow some real cases of discrimination to pass undetected and unremedied by the courts. Under the context-specific proposal, however, only employers who have demonstrated that their decisionmaking systems are not unnecessarily vague and subjective will be entitled to this lower level of scrutiny, whereas currently, virtually all employers, regardless of the uncontrolled subjectivity of their systems, have enjoyed minimal judicial scrutiny by some courts. The possibility that some subtle forms of discrimination will go undetected under the context-specific proposal does not justify maintaining the current jurisprudence, under which even more blatant forms of discrimination go unremedied.

Other critics might argue that employers can circumvent the courts' attempts to scrutinize subjective decision-making systems simply by following formalities and inventing neutral explanations while still relying on their personal biases and preferences. Although it is true some employers will remain intent on promoting only certain types of employees, most employers simply want to promote the most deserving candidates. A context-specific application of employment discrimination theories, by giving these well-intentioned employers the incentive to implement systems that minimize the impact of unconscious biases, will make this goal more achievable.

A context-specific approach also withstands criticism from those who fear that judicial scrutiny will unfairly burden defendant employers, forcing them to alter decision-making systems that have never been proven to be discriminatory. This approach, however, leaves employers broad latitude to devise a satisfactory way to comply with Title VII. An employer need only modify its procedures if it seeks the advantage of less scrutiny and greater deference should the validity of its employment decisions come before a court. Keeping potentially bias-ridden procedures in place will not necessarily lead to liability; it will merely lead to normal Title VII scrutiny in the event of an employment discrimination suit. Thus, employers are free to weigh the costs and benefits of the various strategies. For instance, an employer who believes that its present system is not disproportionately impeding women's advancement might reasonably decide that its system would survive ordinary Title VII scrutiny and should be maintained. By contrast, an employer with ambiguous criteria and unstructured processes might rationally determine that refashioning its hiring system is necessary to minimize judicial scrutiny and reduce its exposure to liability. Most of the measures necessary to minimize subjectivity can be 
implemented at relatively low cost to the employer and are consistent with employers' overall objective of promoting the most qualified employees. Thus, the possibility that judicial scrutiny might cause some nondiscriminating employers to modify their systems is not particularly problematic.

\section{CONCLUSION}

In the thirty years since the enactment of Title VII, women have made significant gains toward equal employment in jobs carrying low to medium amounts of prestige and power. In the uppermost reaches of many professions, however, women are still drastically underrepresented. Studies indicate that this persistent problem is not merely the result of women's different career choices or vocational abilities. Rather, a number of sociological and psychological factors make upper-level employment more elusive for women than for men. The persistence of highly subjective, discretionary decision-making, which fails to control the unexamined and often unconscious biases of the professional elite who make most upper-level employment decisions, exacerbates this phenomenon. Because this cadre of high-level professionals remains predominantly male, the biases that pervade the upper ranks of the job market continue to favor male workers over their female counterparts.

Because traditional Title VII analyses are ill-suited to the small statistical samples and unconscious barriers that usually are associated with upper-level cases, the courts must begin to rethink their approach. A context-specific approach to employment discrimination law would provide the courts with a more effective weapon with which to fight upper-level employment discrimination. Reserving a highly deferential approach for only those employers who demonstrate that their decision-making systems are not arbitrary will provide employers with an incentive to modify their procedures before discrimination occurs. Furthermore, utilizing a traditional level of Title VII scrutiny for all other employers will increase the likelihood that past discriminatory decisions will be identified and remedied. After all, 475 years is too long to wait for equal opportunity for women. ${ }^{255}$

${ }^{255}$ See MORRISON ET AL., supra note 12, at 7 (citing a prediction of the Feminist Majority Foundation). 